\title{
$\frac{((x-))}{4 p e n}$
}

INSTITUTO DE PESQUISAS ENERGÉTICAS E NUCLEARES

Autarquia Associada à Universidade de São Paulo

\section{UTILIZAÇÃO DA CINZA DA CASCA DE ARROZ COMO CARGA EM MATRIZ DE POLIAMIDA 6 SUBMETIDA À RADIAÇÃO IONIZANTE}

\author{
WALDIR PEDRO FERRO
}

Tese apresentada como parte dos requisitos para obtenção do grau de Doutor em Ciências na Área de Tecnologia Nuclear - Aplicações.

Orientador:

Dr. Leonardo Gondim de Andrade e Silva

São Paulo 2009 
Dedico este Trabalho a estas três gerações: Edna, Fernanda e Lorena. 


\section{AGRADECIMENTOS}

Ao Prof. Dr. Leonardo Gondim de Andrade e Silva, pelo apoio, incentivo e paciência ao orientar-me na execução desta pesquisa, apontando os caminhos que norteiam um estudo científico.

Ao Prof. Dr. Hélio Wiebeck por ter sugerido a pesquisa com a Cinza da Casca de Arroz, objeto desta tese de relevante interesse ao meio ambiente, pela preciosa ajuda e apoio na correta interpretação de dados e conceitos relativos à química dos polímeros.

Ao Instituto de Pesquisas Energéticas e Nucleares e ao Centro de Tecnologia das Radiações (CTR) pela oportunidade e apoio não só na realização deste trabalho, mas também por ter estimulado o meu crescimento intelectual em razão da convivência com os profissionais de alto nível que pertencem ao quadro de professores e técnicos deste Instituto.

À Radici Plastics Ltda. pelo apoio material e por ter permitido a execução de ensaios mecânicos e térmicos em seu laboratório, nas pessoas do Sr. Marcos Santana de Araújo, Gerente da Qualidade; Evaldo Benedito Tavares, Analista de Laboratório e Sra. Jane Gomes Campos, Diretora Comercial.

Às empresas CGE Sociedade Fabricadora de Peças Plásticas Ltda. na pessoa do Msc. Salmo Cordeiro do Rosário, e a Tyco Electronics Brasil Ltda. na pessoa do Sr. Eduardo Vinícius Berti, pelo apoio na realização dos testes práticos de injeção com o composto de nylon 6 e CCA, fundamentais para o andamento da pesquisa.

À MARTEC Ind. Com. e Imp. de Mats. Plásticos Ltda. na pessoa do Sr. Antonio Gerger, pelo apoio na produção do composto de CCA sem o qual esta pesquisa não poderia ser realizada.

A todos aqueles que direta ou indiretamente contribuíram para a realização deste trabalho. 


\title{
UTILIZAÇÃO DA CINZA DA CASCA DE ARROZ COMO CARGA EM MATRIZ DE POLIAMIDA 6 SUBMETIDA A RADIAÇÃO IONIZANTE
}

\author{
Waldir Pedro Ferro
}

\section{RESUMO}

Com o propósito de melhorar a estabilidade dimensional, melhorar propriedades de resistência elétrica, mecânica, ao calor entre outras dos polímeros, novas cargas e reforços são testados com esse propósito. As cargas mais utilizadas, para propiciar as características mencionadas anteriormente, são as fibras de vidro e de carbono, as cargas minerais como o carbonato de cálcio precipitado, o talco e a micro esfera de vidro. O objetivo principal deste trabalho foi estudar as potencialidades da cinza da casca de arroz (CCA) como uma carga, já que ela é constituída em $96 \%$ de dióxido de silício e compará-la com o talco que é a carga mineral mais utilizada. Estes estudos foram realizados a partir da elaboração de um composto formado pela cinza da casca de arroz refinada e a poliamida 6 (PA 6) que é um dos principais plásticos de engenharia com aplicações em todas as áreas produtivas. As amostras foram injetadas e irradiadas em um acelerador de elétrons. Posteriormente suas propriedades mecânicas e térmicas foram medidas. Também foram injetadas peças automotivas para verificar a processabilidade da PA 6 com CCA. Os resultados mostraram que a utilização da cinza da casca de arroz como carga para compostos de poliamida 6 é tecnicamente e economicamente viável. A irradiação do composto estudado (PA 6 com 30\% de cinza da casca de arroz) não trouxe melhorias significativas nas propriedades mecânicas e térmicas avaliadas. 


\title{
UTILIZATION OF RICE HUSK ASH AS FILLER FOR POLYAMIDE 6 AND IONIZING RADIATION EFFECT STUDIES ON THIS COMPOSITE
}

\author{
Waldir Pedro Ferro
}

\begin{abstract}
In order to improve the dimensional stability, as well as, electrical, mechanical and thermal properties of polymers, new filler to this purpose has been developed. The most applied filler to propitiate the features previously mentioned are the glass and carbon fibers, the mineral filler as the calcium carbonate, the talc and the micro glass sphere. The main aim of this work was to study the rice husk ash as filler for polyamide 6 and ionizing radiation effect studies on this composite, irradiated by electron beam at different doses, since it is constituted of at least $90 \%$ of silicon dioxide, and compared with the talc which is the most applied mineral filler. This comparison was made from a compound made through the refined rice husk ash and the polyamide 6 (PA 6) which is one of the main engineering plastic with applications in several productive areas. The samples were injected and irradiated in an electron accelerator. Afterwards their mechanical and thermal properties were measured. It was also inject automotive parts to verify the processing of the PA 6 with CCA. The results showed that the use of the rice husk ash as filler for polyamide 6 composite is technically and economically viable. The irradiation of the studied composite (PA 6 with $30 \%$ of rice husk ash) didn't provide any improvement for the mechanical and thermal properties previously appraised.
\end{abstract}




\section{SUMÁRIO}

Página

1 INTRODUÇÃO

2 OBJETIVOS DA PESQUISA ........................................................ 15

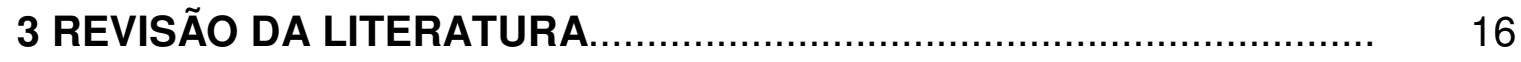

3.1 Poliamida 6 - poli(E-caprolactama) ................................................ 16

3.2 Relação estrutura e propriedades...................................................... 17

3.3 Propriedades características da PA 6 .................................................... 21

3.4 Área de aplicação das poliamidas.................................................... 23

3.5 Cargas minerais....................................................................... 24

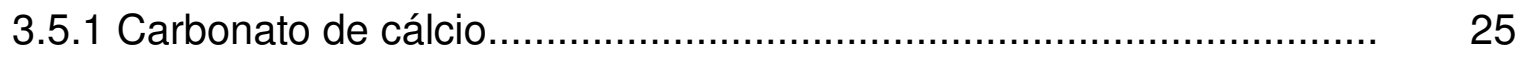

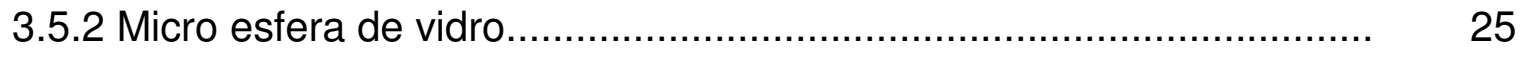

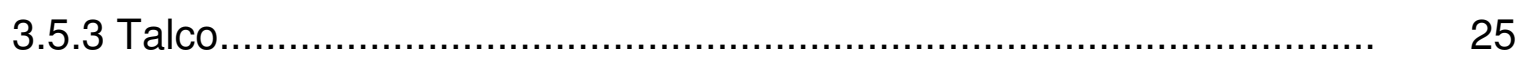

3.6 Casca de arroz ...................................................................... 27

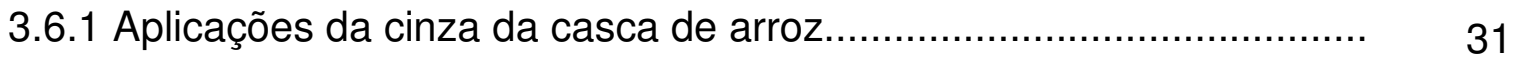

3.6.2 Obtenção da CCA....................................................................... 34

3.6.3 Composição química da CCA e do talco obtidos em literatura........... 35

3.7 Efeito da radiação ionizante em polímeros............................................ 36

3.7.1 Reticulação e cisão................................................................... 40

3.7.2 Aceleradores industriais de elétrons.............................................. 42

3.7.3 Irradiação de poliamida............................................................... 42

3.8 Caracterização de polímeros............................................................. 44

3.8.1 Resistência à tração, módulo de elasticidade e alongamento à 44

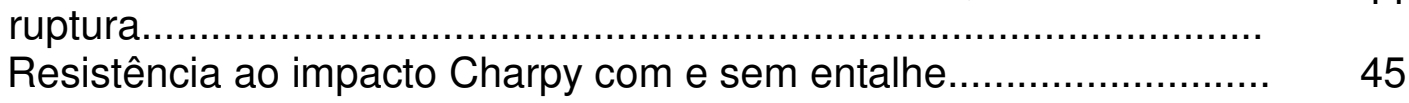

3.8.2 Resistência ao impacto Charpy com e sem entalhe............................ 45

3.8.4 Resistência ao impacto por queda de dardo.................................... 46

3.8.5 Análise de teor de carga................................................................ 46

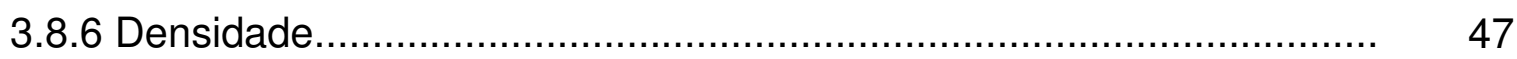


3.8.7 Resistência ao fio incandescente................................................ 47

3.8.8 Calorimetria esploratória diferencial (DSC)..................................... 47

3.8.9 Temperatura de amolecimento Vicat............................................. 48

3.9 Caracterização da CCA............................................................... 48

3.9.1 Espectrometria de fluorescência de Raios X (FRX) .......................... 48

4 MATERIAIS E MÉTODOS................................................................. 50

4.1 Matéria-prima utilizada.................................................................... 50

4.2 Caracterização das amostras........................................................... 50

4.3 Caracterização da PA 6 30\% CM (talco e CCA)................................. 52

4.3.1 Resistência à tração, módulo de elasticidade e alongamento à 52

4.3.2 Resistência ao impacto Charpy com e sem entalhe.................................

4.3.3 Resistência à flexão e módulo de flexão............................................ 53

4.3.4 Resistência ao impacto por queda de dardo..................................... 53

4.3.5 Análise de teor de carga.............................................................. 54

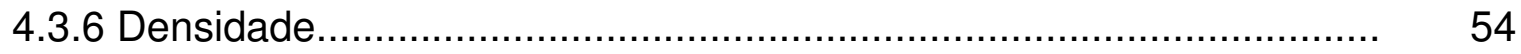

4.3.7 Resistência ao fio incandescente................................................. 55

4.3.8 Calorimetria exploratória diferencial (DSC).................................... 55

4.3.9 Temperatura de amolecimento Vicat.............................................. 55

4.3.10 Teste de aderência e resistência ao impacto de pedras................... 56

4.4 Caracterização da CCA................................................................. 58

4.4.1 Espectrometria de fluorescência de Raio X (FRX) ........................... 58

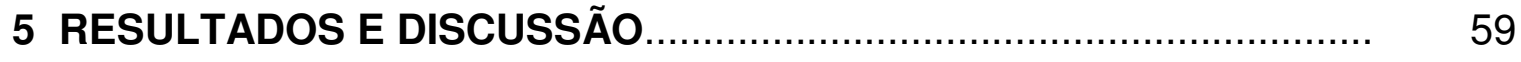

5.1 Caracterização química da CCA...................................................... 59

5.2 Caracterização da PA 6 30\% CM (talco e CCA).................................... 60

5.2.1 Ensaios mecânicos................................................................. 60

5.2.1.1 Ensaios de resistência mecânica, teor de carga e densidade......... 60

5.2.1.2 Teste de aderência em grade e ensaio de resistência ao impacto de batida de pedras................................................................. 63

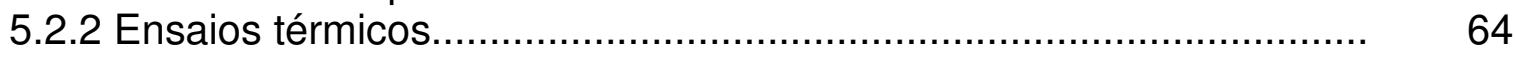

5.2.2.1 Ensaio de fio incandescente....................................................... 64

5.2.2.2 Temperatura de amolecimento Vicat............................................ 64 


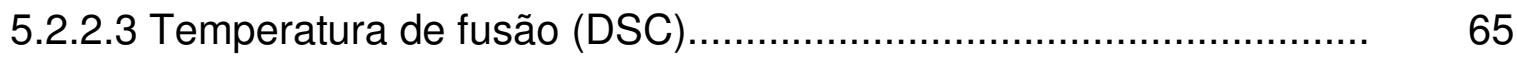

5.3 Moldagem por injeção (processamento)............................................. 66

5.4 Viabilidade econômica.................................................................. 71

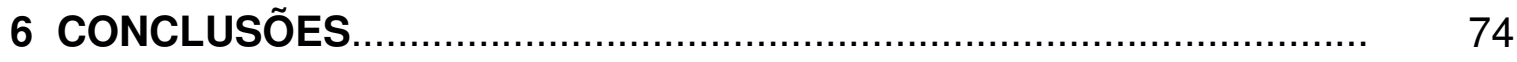

7 SUGESTÕES PARA TRABALHOS FUTUROS.................................... 76

ANEXO A - Normas utilizadas no trabalho ........................................ 77

ANEXO B - Laudo da caracterização da CCA por fluorescência de Raios X........................................................................ 78

REFERÊNCIAS BIBLIOGRÁFICAS.................................................... 80 


\section{LISTA DE TABELAS}

Página

TABELA 1 Variação das propriedades que aumentam e diminuem em função da cristalinidade......

TABELA 2 Características da PA 6 sem carga e com 30\% CM........... 21

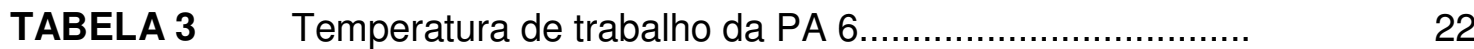

TABELA 4 Composição química em percentagem em peso do talco e da CCA obtidos em literatura.

TABELA 5 Polímeros submetidos à radiação química com cisão e reticulação da cadeia principal, irradiados com baixo LET (Transferência Linear de Energia), à temperatura ambiente, sob vácuo ou na presença de gás inerte..........

TABELA 6 Classificação por aparência da superfície cortada em grade após teste de aderência com fita adesiva.

TABELA 7 Composição química em porcentagem em massa da CCA MS-325.

TABELA 8 Composição química em porcentagem em massa do Talco e da CCA obtidos em literatura e a composição da CCA MS325.

TABELA 9 Ensaios de resistência mecânica, teor de carga e densidade da PA 6 30\% CM (talco) preto e PA $630 \%$ CM (CCA) preto irradiadas e não irradiadas

TABELA 10 Ensaios de fio incandescente, da PA 6 com 30\% de carga mineral (CM) e PA 6 com 30\% de cinza de casca de arroz (CCA) em amostras irradiadas e não irradiadas.

TABELA 11 Ensaio de amolecimento Vicat da PA 6 com 30\% de carga mineral (CM) e PA 6 com $30 \%$ de cinza de casca de arroz (CCA) em amostras irradiadas e não irradiadas.

TABELA 12 Temperatura de fusão da PA 6 30\% CM e 30\% CCA irradiadas e não irradiadas.

TABELA 13 Parâmetros de injeção para a capa de correia GM em PA 6 $30 \% \mathrm{CM}$ 
TABELA 14 Custo total/kg para a fórmula de PA 6 30\% CM (talco)

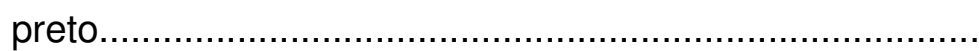

TABELA 15 Custo total/kg para a fórmula de PA $630 \%$ CM (CCA)

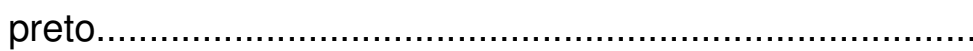

TABELA 16 Custo total/kg para a fórmula de PA 6 30\% CM (talco) MI preto....................................................................... 


\section{LISTA DE FIGURAS}

Página

FIGURA 1 Representação esquemática das moléculas de PA 6 e PA

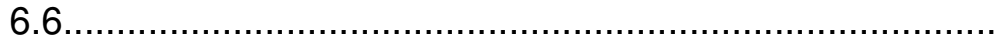

FIGURA 2 Representação esquemática das ligações amida-amida na PA

6.

FIGURA 3 Representação esquemática da absorção de água pela PA

6.

FIGURA 4 Secção longitudinal da casca de arroz mostrando: (1) epiderme externa, (2) fibra esclerênquima, (3) célula parênquima e (4) epiderme interna.

FIGURA 5 Câmara de combustão da CA (caldeira), turbina, gerador e centro de controle da termoelétrica da Arrozeira

Urbano

FIGURA 6 Micrografia feita em MEV de cinza de casca de arroz onde se pode observar a estrutura original de sílica amorfa (1000x).

FIGURA 7 Seqüência de fotos que mostram a produção da CCA. Na imagem (a) tem-se o arroz a ser beneficiado, na (b) o aglomerado de casca chamado briquete, na (c) a cinza logo após a queima da casca, na (d) a cinza já micronizada, na (e) o polímero base e na (f) a CCA incorporada ao polímero base.

FIGURA 8 Sistema de feixe de varredura do acelerador de elétrons do Centro de Tecnologia das Radiações do IPEN.

FIGURA 9 Equipamento de resistência ao impacto por queda de dardo.

FIGURA 10 Esquema de equipamento de batida de pedra.....................

FIGURA 11 Padrão de aparência de resistência ao impacto de pedras da superfície mais resistente (a) para a menos resistente (f)

FIGURA 12 Tensão em função do alongamento da PA 6 30\% CM e PA 6 $30 \%$ CCA 
FIGURA 13 Peças submetidas ao ensaio de batida de pedras e de aderência por corte em grade de pintura na portinhola do automóvel Pólo VW...........................................................

FIGURA 14 Representação de uma rosca universal da unidade de plastificação de uma máquina injetora de plásticos..............

FIGURA 15 Capa de correia GM injetada com PA 6 30\% CCA preto em injetora Haitian de 350t de fechamento e molde com 1

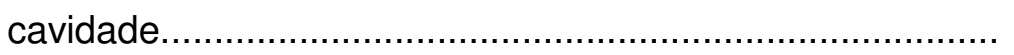

FIGURA 16 Máquina injetora Haitian utilizada na injeção da capa de correia GM com o molde da tampa de correia aberto........... 68

FIGURA 17 Esquema de uma máquina injetora de termoplásticos......... 69

FIGURA 18 Portinhola da tampa do combustível do automóvel Pólo VW injetado com PA $630 \%$ CCA preto em injetora Romi de 300t de fechamento e molde com 2 cavidades................

FIGURA 19 Portinhola da tampa de combustível do automóvel Pólo VW pintada com fundo PU, base prata e acabamento em verniz acrílico catalisado

FIGURA 20 Conector VW Fox injetado com PA 6 30\% CCA preto em injetora Engle de $200 \mathrm{t}$ de fechamento e molde com 2

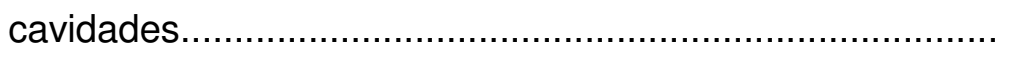




\section{INTRODUÇÃO}

$\mathrm{Na}$ relação entre o homem e o meio ambiente, ninguém está levando vantagem já faz algum tempo. O planeta dá preocupantes sinais de esgotamento, como o aumento do buraco na camada de ozônio e as alterações climáticas em todo o mundo, colocando em risco o futuro da nossa existência ${ }^{[1]}$.

$\mathrm{O}$ avanço e a conquista tecnológica na Medicina e Agricultura fizeram com que a população mundial passasse de um bilhão no final do século XIX para quase cinco bilhões no final do século passado, podendo chegar a oito bilhões nos próximos 30 anos, o que implicará no aumento do uso das reservas do planeta, da produção de bens e também da geração de lixo ${ }^{[1]}$.

Atrelado a tudo isto, vem o aumento da poluição do solo, das águas (subterrâneas e de superfície) e do ar, levando a um contínuo e acelerado processo de deterioração de nosso ambiente, com uma série de implicações na qualidade de vida de seus habitantes e nos seus bens naturais ${ }^{[1]}$.

Para atender uma demanda de produtos cada vez maior são desenvolvidos novos processos visando o aumento da produtividade e a respectiva redução de custos, exercendo uma pressão cada vez maior sobre o meio ambiente uma vez que para se obter as matérias-primas necessárias à produção desses bens de consumo o homem é obrigado a interferir diretamente na natureza.

O alarme sobre o impacto das atividades antrópicas sobre o meio ambiente foi dado fazendo com que as empresas instituíssem a estratégia da "atuação responsável" visando reduzir o impacto ambiental das atividades industriais ${ }^{[2]}$.

Nessa linha os órgãos de pesquisa têm uma participação fundamental na prospecção de novos processos que visam reaproveitar e ou reciclar os resíduos provenientes não só dos processos industriais como os gerados na agricultura e na sociedade civil em geral. Neste sentido, este trabalho procura dar uma contribuição para o aproveitamento da casca de arroz em atividades industriais, um resíduo agrícola que traz sérios transtornos ao meio ambiente quando descartado sem os controles adequados devido aos altos números de resíduos gerados por essa cultura em todo o mundo. 
Dentre os processos industriais o desenvolvimento de novos materiais plásticos e compostos tem um papel de destaque. Devido a sua fácil processabilidade, boa resistência mecânica, boa resistência à temperatura e ciclos produtivos cada vez menores, permite a produção em escala de peças e componentes que até então eram produzidos em metal, com maior produtividade e custos reduzidos ${ }^{[3]}$.

Paralelamente ao desenvolvimento de novos materiais, são elaboradas novas cargas e reforços com o objetivo de proporcionar a esses polímeros melhor estabilidade dimensional, melhores propriedades de resistência elétrica, mecânica, ao calor entre outras.

As cargas mais utilizadas, para propiciar as características mencionadas anteriormente, são as fibras de vidro e de carbono, as cargas minerais como o carbonato de cálcio precipitado, o talco e a micro esfera de vidro.

Optou-se por trabalhar nesta pesquisa com a poliamida 6 porque em levantamento interno de mercado realizado em 2007 pela empresa Radici Plastics Ltda, com sede em Araçariguama, SP, Brasil, o mercado de poliamida virgem (PA 6 e PA 6.6 compostos e não compostos) no Cone sul é aproximadamente 80.000 t/ano sendo que o Brasil responde pelo consumo de 70.000 t/ano seguido da Argentina com 5.000 t/ano e os demais países da América do Sul são os responsáveis pelas outras 5.000 t/ano. O Brasil responde pelo consumo de mais 10.000 t/ano de poliamidas 6 e 6.6 recicladas enquanto que nos outros países devido a baixa utilização não há estatísticas para este consumo, mostrando ser a PA 6 um dos mais importantes plástico de engenharia na indústria automobilística, elétrica, civil, alimentícia entre outros. Nesta pesquisa tomou-se como base o composto de PA 6 $30 \%$ carga mineral (PA $630 \% \mathrm{CM}$ ) por ser este o mais usual e representativo dentre as especificações, muito embora também se especifique compostos com 20 e $40 \%$ de carga mineral.

$\mathrm{Na}$ literatura existem trabalhos sobre o efeito da radiação ionizante em poliamidas 6 e $6.6 \mathrm{com}$ e sem reforços ${ }^{[4-10]}$, mas não foi encontrada nenhuma referência ou trabalho utilizando a cinza da casca de arroz como carga para poliamida 6 e submetidas a radiação ionizante. 


\section{OBJETIVO DA PESQUISA}

O objetivo principal deste trabalho é mostrar a viabilidade técnica e econômica da utilização da cinza da casca de arroz (CCA) como carga em poliamida 6 (PA 6) e compará-la com o talco que é carga mineral mais utilizada. Essa comparação foi feita a partir da elaboração de um composto constituído pela cinza da casca de arroz refinada e a poliamida 6 (PA 6) que é um dos principais plásticos de engenharia com aplicações em todas as áreas produtivas, injetar corpos-de-prova e irradiá-los em acelerador de elétrons industrial e avaliar as suas propriedades mecânicas e térmicas.

Nesta pesquisa tomou-se como base o composto de PA 6 30\% carga mineral (PA $630 \%$ CM) por ser este o mais usual e representativo dentre as especificações, muito embora também se especifique compostos com 20 e $40 \%$ de carga mineral. 


\section{REVISÃO DA LITERATURA}

\subsection{Poliamida 6 - poli( $\varepsilon$-caprolactama)}

A palavra "Nylon" tem sido aceita como um termo genérico para as poliamidas sintéticas alifáticas. $\mathrm{O}$ grupo funcional amida $(-\mathrm{CONH}-)$ é característico para todas poliamidas (PA) e as macromoléculas de PA 4.6; PA 6.6; PA 6; PA 6.9; PA 6.10; PA 6.12; PA 11 e PA 12. Essas macromoléculas são cadeias alifáticas lineares unidas por ligações amida/amida para formar polímeros de massa molar numérica média (Mn) entre 11.000 e $40.000 \mathrm{~g} / \mathrm{mol}^{[11]}$.

As poliamidas são termoplásticos semicristalinos de fácil processabilidade, com boa resistência mecânica e química. Estas poliamidas são designadas por números que indicam a quantidade de átomos de carbono nas unidades monoméricas originais. Os polímeros derivados de aminoácidos ou lactamas são designados por um único número, enquanto que os preparados pela reação de diaminas e ácidos dibásicos são designados por dois números, onde o primeiro representa a diamina.

A PA 6, por exemplo, é obtida a partir da caprolactama, um composto orgânico que possui 6 átomos de $C$ na sua composição. A PA 6.6 é obtida a partir do ácido adípico que possui 6 átomos de $C$ na sua estrutura e da hexametilenodiamina que também possui 6 átomos de $C^{[12]}$.

Apesar das poliamidas 6 e 6.6 serem obtidas de matérias-primas diferentes, as suas moléculas, mostradas na Figura 1, são bastante parecidas diferenciando-se apenas pelo número de átomos de $\mathrm{C}$ e os grupos amida presentes na molécula.<smiles>CC(C)(C)CCCCC(=O)NC(C)(C)C</smiles>

PA 6 - poli( $\varepsilon$-caprolactama)

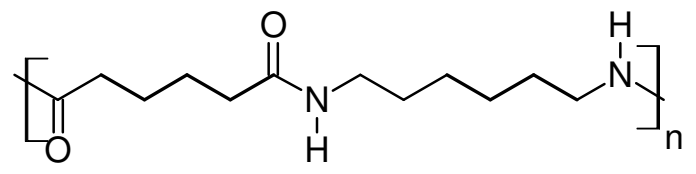

PA 6.6 - poli(hexametilenoadipamida)

FIGURA 1 - Representação esquemática das moléculas de PA 6 e PA 6.6 $6^{[12,13]}$

A PA 6 pode ser obtida a partir da hidrólise da caprolactama, abrindo a cadeia e em etapas sucessivas de polimerização por condensação e adição. 
A $\varepsilon$-caprolactama pode ser obtida a partir do benzeno ou do fenol representada esquematicamente na reação (1) apresentada na seqüência ${ }^{[11]}$.

(1)

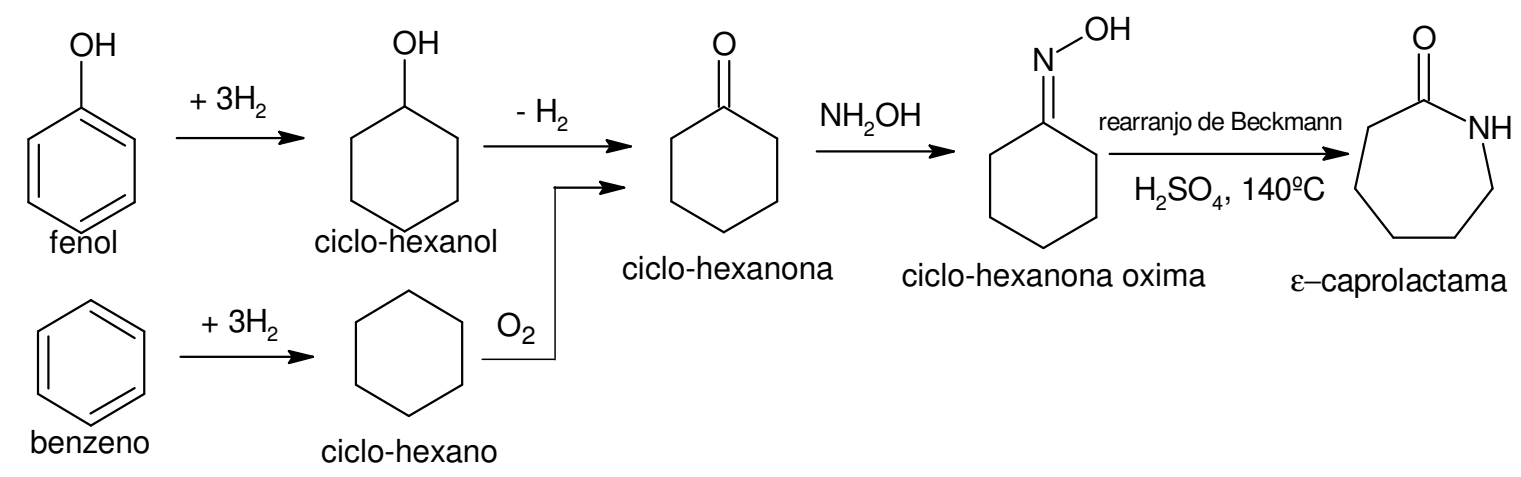

No esquema da reação (2) mostra-se a representação da polimerização do náilon 6, preparado a partir da abertura do anel da $\varepsilon$-caprolactama por hidrólise ${ }^{[11]}$.

(2)<smiles>CNC(=O)C(C)CCCCNC(=O)C(C)C</smiles>

Neste processo, a $\varepsilon$-caprolactama reage com a água e é parcialmente convertida a ácido $\varepsilon$-aminocapróico ou sal de náilon que reage com a $\varepsilon$-caprolactama à $250^{\circ} \mathrm{C}$ liberando a água para a produção da poliamida. $O$ náilon 6 também pode ser convertido em fibras pelo processo de fiação da massa fundida e em pellets ${ }^{[11]}$.

\subsection{Relação estrutura e propriedades}

As poliamidas alifáticas tais como as poliamidas 6, 6.6, 6.10, 11 e 12 são polímeros lineares, e deste modo, termoplásticos. Elas contém grupos amida polares 
$(-\mathrm{CONH}-)$ espaçados regularmente, e por isso cristalizam com grande atração intermolecular. Essas cadeias poliméricas também possuem segmentos de cadeia alifáticos que levam a uma certa flexibilidade na região amorfa. Deste modo, a combinação da grande atração intercadeias nas zonas cristalinas e flexibilidade nas zonas amorfas faz com que esses polímeros sejam tenazes acima de suas temperaturas de transição vítrea ${ }^{[14,15]}$.

A estrutura cristalina depende do arranjo das cadeias moleculares. Se o arranjo for muito ordenado tridimensionalmente, o polímero é dito ter um grau de cristalinidade alto. A atração intermolecular alta gera polímeros com temperatura de fusão alta. De qualquer modo, acima da temperatura de fusão, a viscosidade é baixa devido à flexibilidade do polímero em tais temperaturas ${ }^{[16]}$.

A estrutura cristalina das poliamidas depende, em primeira instância, da concentração dos grupos amida e da simetria molecular. As unidades repetitivas mais curtas entre os grupos amida $(-\mathrm{CONH}-)$ permitem às cadeias poliméricas se disporem numa conformação zig-zag planar compacta com ligações de hidrogênio entre elas.

As unidades repetitivas mais longas (isto é, maior distância entre os grupos repetitivos (-CONH-) tal como no caso da poliamida 11 , diminuem a atração molecular (menor cristalinidade e menor ocorrência de ligações de hidrogênio) e, conseqüentemente, reduzem a capacidade de cristalização e também as propriedades do polímero em relação a resistência mecânica e térmica, porém apresentam resistência superior à absorção de água. As poliamidas de unidades repetitivas mais curtas (maior número de ligações de hidrogênio), tal como no caso da PA 6 e PA 6.6, apresentam altos valores de absorção de água em relação às poliamidas $6.10,11$ e $12^{[12,14]}$.

Na Figura 2 é mostrada a representação esquemática das ligações amidaamida numa molécula de PA 6. 


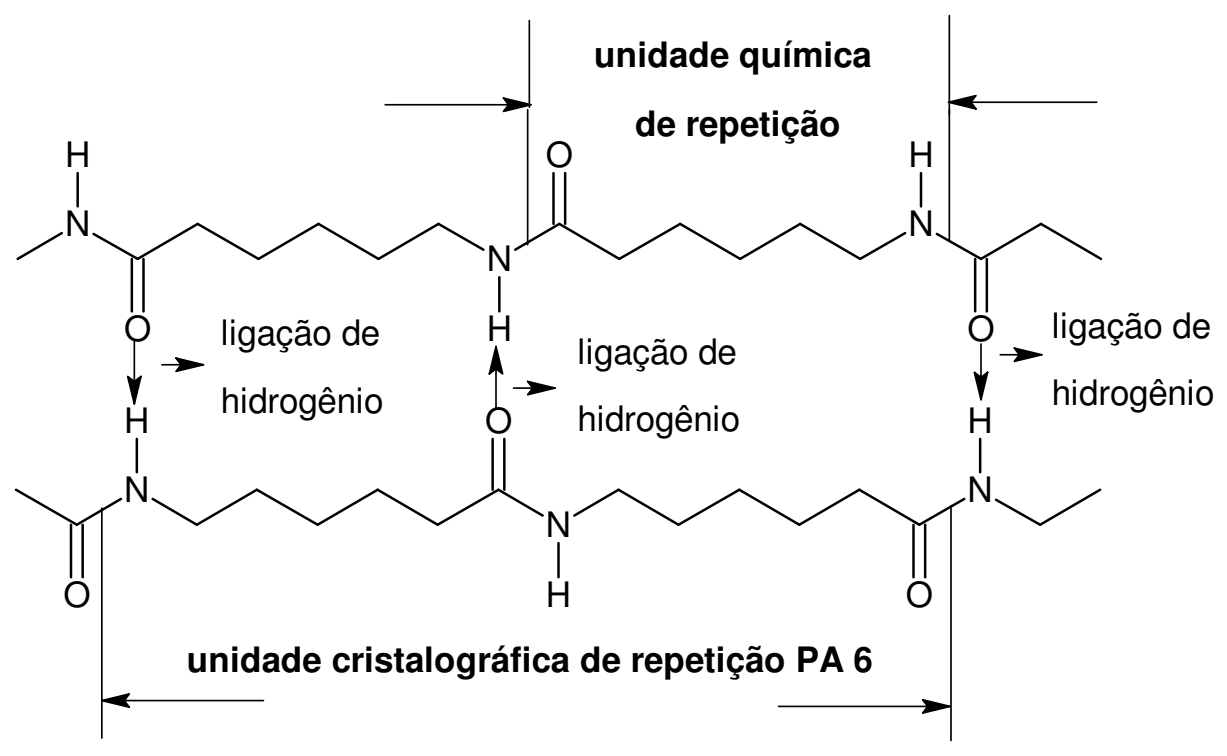

FIGURA 2 - Representação esquemática das ligações amida-amida na PA 6

A influência do grau de cristalinidade das poliamidas é marcante nas propriedades físicas do material. No entanto, o efeito da cristalinidade dificilmente pode ser discutido independentemente da absorção de água pelas poliamidas, devido à natureza higroscópica das ligações de hidrogênio que se transformam em hidroxilas.

A presença de água funciona como plastificante no polímero, separando as cadeias moleculares e diminuindo a cristalinidade e a temperatura de transição vítrea $\left(\mathrm{T}_{\mathrm{g}}\right)$ do polímero de um valor da ordem de $30^{\circ} \mathrm{C}$ variando de $50^{\circ} \mathrm{C}$ para $20^{\circ} \mathrm{C}$.

Conseqüentemente, reduz-se por um lado a rigidez e a resistência à fluência das poliamidas e por outro lado aumenta-se a resistência ao impacto e a tenacidade das mesmas. A absorção de água interfere na cinética de cristalização das poliamidas. Como a $T_{g}$ da PA 6.6 rigorosamente seca é da ordem de $50^{\circ} \mathrm{C}$ e com absorção normal de umidade este valor é reduzido para aproximadamente abaixo da temperatura ambiente, isto influi na cinética de cristalização pós-moldagem que prossegue muito lentamente, resultando em efeitos de encolhimento pós-moldagem que irão estabilizar somente num período não inferior a dois anos. No caso de PA 6 este efeito negativo é menos significativo ${ }^{[12,17,18]}$.

Em seguida apresenta-se a variação de algumas propriedades com o grau 
de cristalinidade de um polímero.

$\mathrm{Na}$ Tabela 1 apresentam-se as propriedades que aumentam e as propriedades que diminuem em função da cristalinidade do polímero.

\section{TABELA 1 - Variação das propriedades que aumentam e diminuem em função da cristalinidade ${ }^{[14]}$}

\begin{tabular}{cc}
\hline Propriedades que aumentam & Propriedades que diminuem \\
\hline Densidade & Alongamento na ruptura \\
Módulo de elasticidade & Resistência ao impacto \\
Resistência à tração & Tenacidade \\
Dureza e resistência à abrasão & Expansão térmica \\
$\mathrm{T}_{\mathrm{m}}$ e $\mathrm{T}_{\mathrm{g}}$ & Permeabilidade \\
Estabilidade dimensional & Resistência à fadiga \\
Resistência química & \\
Resistência elétrica & \\
\hline
\end{tabular}

Como se pode notar, quanto mais cristalino o polímero, maior a sua rigidez mecânica e menor a sua tenacidade.

A interação entre o grau de cristalinidade e o teor de umidade do polímero é um fator crítico, visto que estes dois fatores apresentam efeitos opostos nas propriedades físicas, químicas e mecânicas da poliamida. De um lado, o aumento na cristalinidade significa propriedades de resistência superiores (tração, rigidez e fluência), dureza e resistência à abrasão alta, estabilidade dimensional boa (temperatura de termo-distorção superior, absorção de água menor e encolhimento pós-moldagem), propriedades elétricas e químicas boas. Por outro lado, a absorção de água reduz o grau de cristalinidade, deteriora as características do polímero, mencionadas anteriormente, porém apresentam vantagens de tenacidade e resistência ao impacto superior.

Visto que as PA 6 e PA 6.6 somente atingem a tenacidade ótima após estabilização com 1-2\% de umidade, seus produtos não podem ser colocados imediatamente em serviço. A densidade de energia coesiva alta e a estrutura cristalina das poliamidas resultam em resistência química boa, sendo que quanto maior o grau de cristalinidade, mais alta será a resistência das poliamidas ao ataque 
químico.

Na Figura 3 é mostrada como a molécula de água penetra entre as de PA 6 que devido a sua polaridade ocorrem as ligações por hidrogênio. A molécula de água ao ser absorvida pelo polímero aumenta o espaçamento entre as moléculas poliméricas, aliviando as tensões intermoleculares. A água funciona como um plastificante $^{[12,14,19]}$.

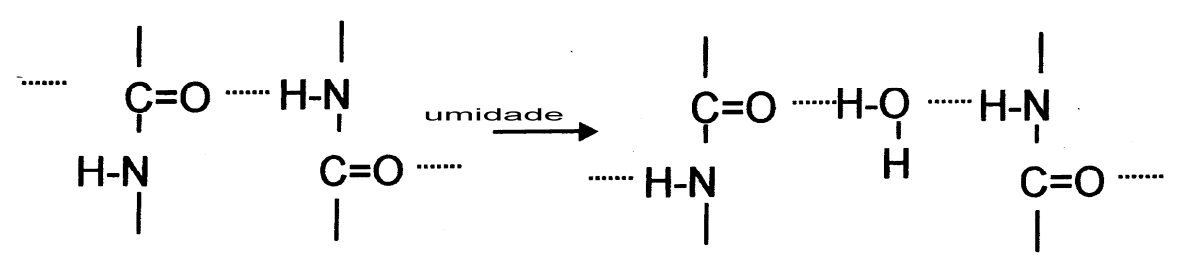

FIGURA 3 - Representação esquemática da absorção de água pela PA 6

\subsection{Propriedades características da PA 6}

$\mathrm{Na}$ Tabela 2 são apresentadas os valores de algumas das principais características físicas da poliamida 6 sem carga e da poliamida $630 \%$ carga mineral (CM) de grande interesse comercial por serem os mais especificados pelas montadoras de veículos automotores ${ }^{[20,21]}$.

TABELA 2 - Características da PA 6 sem carga e com 30\% CM

\begin{tabular}{lccc}
\hline \multicolumn{1}{c}{ Propriedades } & Norma & PA 6 & PA 6 30\% CM \\
\hline Temperatura de Fusão $\left({ }^{\circ} \mathrm{C}\right)$ & $-\mathrm{x}-$ & $215-225$ & $215-225$ \\
Densidade $\left(\mathrm{g} / \mathrm{cm}^{3}\right)$ & ISO 1183 & 1,13 & 1,30 \\
Resistência à Tração (MPa) & ISO 527 & $70-80$ & 65 \\
Módulo de Flexão (MPa) & ISO 178 & 2900 & 5000 \\
Absorção de Água (\%) & ASTM D 570 & $1,1-1,3$ & $0,7-0,9$ \\
Resistência à Flexão (MPa) & ISO 178 & 120 & 115 \\
Impacto Charpy c/ entalhe $\left(\mathrm{kJ} / \mathrm{m}^{2}\right)$ & ISO 179 & 5,0 & 4,0 \\
Flamabilidade & UL 94 & V2 & HB \\
\hline
\end{tabular}

No ensaio de flamabilidade determina-se a velocidade de queima de materiais plásticos aditivados com retardantes de chama. Foi desenvolvido pelo 
"Underwriters Laboratories" (UL) e é um dos testes mais utilizados e mais freqüentemente citados em especificações de flamabilidade em materiais plásticos que classifica os polímeros nas classes HB, V2, V1 e V0. Na classificação V2 o polímero propaga chama, mas após alguns segundos auto-extingue e na classificação HB a chama deve se propagar horizontalmente numa velocidade inferior a $40 \mathrm{~mm} / \mathrm{min}$ em corpo-de-prova definido pela norma UL 94 que estabelece as condições do ensaio.

A incorporação da carga mineral diminui as características de resistência mecânica e de flamabilidade da poliamida 6 , mas reduz significativamente os efeitos negativos da plastificação do polímero com a absorção de água pela simples razão de diminuir o volume de polímero hidroxilável no composto proporcionando melhor estabilidade dimensional pós-moldagem ${ }^{[14,22,23]}$ ao produto final.

Uma das características das poliamidas está na sua estreita faixa de temperatura de fusão. Nas temperaturas abaixo desta faixa, o material ainda está sólido, mas nas temperaturas acima, ele se torna fluído.

A temperatura de fusão das poliamidas permitem que sejam utilizadas em temperaturas de trabalho relativamente altas.

$\mathrm{Na}$ Tabela 3 são apresentadas as temperaturas limites de trabalho da poliamida $6^{[23]}$.

TABELA 3 - Temperatura de trabalho da PA 6

\begin{tabular}{|c|c|c|c|}
\hline POLIAMIDA & $\begin{array}{c}\text { TRABALHO } \\
\text { CONTÍNUO (ํㅡ) }\end{array}$ & $\begin{array}{c}\text { TRABALHO } \\
\text { ESPORÁDICO (ํㅡ) }\end{array}$ & $\begin{array}{l}\text { TEMPERATURA } \\
\text { DE FUSÃO (응 }\end{array}$ \\
\hline PA 6 & $80-100$ & $140-160$ & $217-223$ \\
\hline
\end{tabular}

As resinas de poliamidas não possuem uma perfeita estabilidade à oxidação quando submetidas ao calor e aos raios ultravioletas na presença de ar.

A sensibilidade à oxidação é muito alta quando o polímero está no estado de fusão. A exposição prolongada ao ar causa considerável amarelecimento acompanhado pelo fenômeno de degradação. Abaixo da temperatura de fusão essa sensibilidade diminui conforme diminui a temperatura. Entretanto, em temperaturas que excedem 70 a $80^{\circ} \mathrm{C}$, a superfície do produto pode tornar-se amarelada. 
Em geral, sob condições de temperatura de trabalho, a variação de cor possui apenas um efeito superficial, não provocando mudanças significativas nas propriedades do produto acabado, especialmente se a espessura não for particularmente pequena. As poliamidas não possuem estabilidade à cor quando submetidas á radiação ultravioleta. Quando as poliamidas são utilizadas em aplicações que requeiram exposição à luz solar, deve-se utilizar na sua fórmula aditivos específicos para essa aplicação.

As poliamidas têm uma boa resistência a hidrocarbonetos alifáticos e aromáticos; óleos vegetais, animais e minerais e gorduras; sais em soluções neutras ou alcalinas; cetonas; ésteres; álcoois; ácidos orgânicos, exceto ácido fórmico.

Possuem pouca resistência a soluções diluídas de ácidos inorgânicos e a alguns hidrocarbonetos clorados. Ácido acético, ácido fórmico concentrado, fenóis e cresóis dissolvem a poliamida.

A resistência química de materiais altamente cristalinos é, em geral, um pouco maior do que os correspondentes produtos amorfos ${ }^{[12,23]}$.

\section{4 Área de aplicação das poliamidas}

Como os principais termoplásticos de engenharia, em termos de volume de material consumido mundialmente para estas aplicações, as poliamidas (PA 6 e PA 6.6) devem esta posição não apenas à excelente combinação de propriedades físicas e mecânicas, que incluem grau de resistência à abrasão alta, coeficiente de atrito baixo, resistência ao impacto e resistência a solventes, mas também ao seu custo relativamente competitivo devido à grande capacidade de produção mundial dos seus monômeros, fabricados principalmente para atender o grande consumo das fibras têxteis ${ }^{[23,24]}$.

A área de aplicações dos diversos tipos de PA 6 e PA 6.6 não modificadas/reforçadas é bastante ampla, apresentando aplicações de engenharia tais como na indústria automobilística (principal área de consumo da PA 6.6 nos EUA), indústria elétrica (principal área de consumo da PA 6 na Europa), indústria de construção e móveis e na engenharia mecânica leve e de precisão. As aplicações típicas na indústria automobilística com os tipos de poliamidas reforçadas com fibra 
de vidro incluem maçanetas, puxadores e componentes de fechaduras das portas de carro. Aplicações no compartimento do motor incluem recipientes para água, óleo lubrificante, carcaças de filtros de gasolina, ventoinhas do radiador, caixas de água do radiador, sistemas de aquecimento do carro entre outros.

Os principais critérios para seleção do material composto em preferência aos demais termoplásticos de engenharia são: resistência mecânica alta sob condições de fadiga e impacto repetitivo, resistência à temperaturas elevadas e ambientes agressivos de serviço, custo relativamente baixo da resina. Uma aplicação que vem se desenvolvendo bastante nos últimos anos são as calotas de PA 6 reforçada tanto com fibra de vidro quanto com carga mineral.

$\mathrm{Na}$ indústria elétrica, os tipos de PA 6 e PA 6.6 reforçados com fibra de vidro e aditivos antichama são empregados para a confecção das carcaças de ferramentas elétricas manuais, coberturas de interruptores, plugs, conectores e carcaças dos tambores de máquinas de lavar automáticas.

$\mathrm{Na}$ indústria de engenharia mecânica leve e de precisão, as poliamidas 6 e 6.6 destacam-se principalmente na fabricação (por moldagem ou usinagem) de engrenagens, rolamentos, mancais e buchas de vedação e de impacto, onde diversos tipos não carregados e outros reforçados com fibra de vidro e ou agentes lubrificantes (grafite, politetrafluoroetileno e bissulfeto de molibdênio) são usados de acordo com o tipo de solicitação mecânica e ambiente de serviço ${ }^{[12,14,23]}$.

\subsection{Cargas minerais}

São substâncias que alteram a resistência à temperaturas altas e baixas. Além disso, proporcionam estabilidade dimensional ótima (diminuição da contração na moldagem) e diminuição na absorção de água. Devido ao seu preço relativamente baixo, pode reduzir custos, dependendo da percentagem utilizada na composição da resina ${ }^{[12,14]}$. 


\subsubsection{Carbonato de cálcio}

O carbonato de cálcio $\left(\mathrm{CaCO}_{3}\right)$ ou mármore com partículas de diâmetro menor que $3 \mu \mathrm{m}$ e superfície específica de 6 a $7 \mathrm{~m}^{2} / \mathrm{g}$ é empregado como agente econômico para aumentar a rigidez, pelo aumento da resistência à temperatura, estabilidade dimensional ao produto acabado, reduz a absorção de água e a contração na moldagem, melhora a resistência ao impacto com entalhe e a dureza superficial. $\mathrm{O} \mathrm{CaCO}_{3}$ quando empregado como carga no PVC melhora a resistência à flamabilidade mediante a formação de ácido clorídrico $(\mathrm{HCl})$.

A desvantagem na utilização do $\mathrm{CaCO}_{3}$ é o acabamento superficial inferior que destaca as marcas de fluxo do material produzindo manchas indesejáveis na peça moldada. Esse problema pode ser minimizado utilizando-se o carbonato de cálcio precipitado com diâmetro menor que $0,7 \mu \mathrm{m}$ e superfície específica maior que $30 \mathrm{~m}^{2} / \mathrm{g}$, porém, seu custo elevado torna inviável a sua aplicaçãa[ ${ }^{[14,25,26]}$.

\subsubsection{Micro esfera de vidro}

A micro esfera de vidro melhora a rigidez e a estabilidade dimensional. Além disso, acelera o ciclo de produção e facilita a moldagem apesar de causar desgaste nos equipamentos ${ }^{[12,14]}$.

\subsubsection{Talco}

O talco é um mineral funcional que apresenta aplicações muito exclusivas derivadas da textura lamelar e hidrofobicidade de suas partículas e a dureza baixa, a mais baixa na escala de Mohs, e área específica de 6 a $20 \mathrm{~m}^{2} / \mathrm{g}$. É um silicato de magnésio, com a composição teórica de $3 \mathrm{MgO} .4 \mathrm{SiO}_{2} \cdot \mathrm{H}_{2} \mathrm{O}$, os tipos de talco mais comuns comercialmente são a clorita e a dolomita ${ }^{[25,26]}$.

Os minérios mais puros são aqueles de origem metamórfica. Os talcos de origem ultrabásica já têm teores de ferro mais elevados e a presença de contaminantes como minerais fibrosos ou traços de cobre e manganês podem 
comprometer sua aplicação geral. Teores significativos de alumínio e ferro podem estar presentes na estrutura cristalina do mineral.

A importância da pureza do talco se deve às suas aplicações para consumo humano direto (cosméticas, farmacêuticas e alimentícias). A estrutura cristalina do talco é formada por duas folhas de $\mathrm{SiO}_{2}$, unidas entre si por camadas de brucita $\left[\mathrm{Mg}(\mathrm{OH})_{2}\right]$, e que se estendem indefinidamente em todas as direções do plano. A dureza baixa do talco é derivada da energia baixa das ligações de van der Waals que unem as folhas de sílica de cada cristal.

Estas ligações se rompem facilmente sobre ação mecânica. No processo de moagem para a geração de partículas finas de talco os grãos e partículas mais grossas são preferencialmente delaminadas, em relação às fraturas perpendiculares que rompem ligações covalentes de energia mais elevada, criando lamelas muito finas. Só nas espessuras abaixo de $10 \mu \mathrm{m}$, como tese, utilizando equipamentos especiais (micronizadores com ar comprimido ou vapor superaquecido) as partículas começam a ser quebradas com mais intensidade na direção perpendicular, mas ainda mantendo a morfologia lamelar ${ }^{[27]}$.

Os talcos do Estado de Montana, nos Estados Unidos, e do Estado do Paraná, no Brasil, ocorrem como agregados de partículas lamelares muito finas que no processo de moagem se reduzem a agregados menores em forma não necessariamente lamelar e micro-partículas lamelares.

As aplicações industriais do talco são devidas as suas propriedades funcionais, que são:

A lamelaridade alta das partículas, a dureza baixa e a energia baixa entre partículas, a conseqüente suavidade e o livre escoamento:

* talco em pó perfumado ou não para aplicação no corpo de adultos e crianças;

* talco desodorante;

* antiaderente de uso geral;

* aplicações farmacêuticas e alimentícias.

A lamelaridade alta das partículas e a organoficidade de suas superfícies planares de sílica:

* carga e reforço de compostos termoplásticos; 
* carga funcional em papel;

* pigmento de "coating" para papel.

Hidrofobicidade de suas partículas:

* controle de "pitch" em fábricas de celulose e papel;

A lamelaridade alta das partículas e comportamento reológico exclusivo em suspensões aquosas e orgânicas:

* carga extensora de propriedades reológicas, óticas e mecânicas em tintas imobiliárias e industriais.

Componente da massa cerâmico e aditivo de esmaltes e engobes ${ }^{[27]}$.

O talco com grandes aplicações na indústria automobilística, mecânica e eletrônica, confere estabilidade dimensional superior ao produto acabado. Além disso, reduz a absorção de água e a contração na moldagem, aumentando a resistência à deflexão térmica. Tem a desvantagem de alterar o acabamento superficial da peça. O talco é adicionado aos termoplásticos por simples mistura mecânica, pois existem agentes de ligação (silanos) que servem como ponte entre o talco e o polímero melhorando a performance do produto acabado ${ }^{[12,14]}$.

\subsection{Casca de arroz}

A casca de arroz (CA) é um revestimento ou capa protetora formada durante o crescimento dos grãos de arroz. Removidas durante o refino do arroz, estas cascas possuem baixo valor comercial, pois o $\mathrm{SiO}_{2}$ e as fibras contidas não possuem valor nutritivo e por isso não são usadas na alimentação humana ou animal ${ }^{[28]}$.

A CA é constituída por $50 \%$ de celulose, $30 \%$ de lignina e $20 \%$ de resíduo inorgânico. O resíduo inorgânico contém, em média, 95 a 98\% em massa de sílica, na forma amorfa hidratada, dependendo da espécie e local de plantio.

A CA é composta basicamente de quatro camadas estruturais fibrosas, esponjosas ou celulares, que são altamente silicosas: 1) epiderme externa, coberta com uma espessa cutícula de células silificadas onde é encontrada a espícula (pêlo); 2) esclerênquima ou fibra hipoderme, com paredes espessas lignificadas e 
silificadas; 3) célula parênquima esponjosa e 4) epiderme interna com células geralmente isodiamétricas.

Na Figura 4 é mostrado o mapeamento da distribuição da sílica na CA. A sílica está mais concentrada na epiderme externa ${ }^{[29]}$.

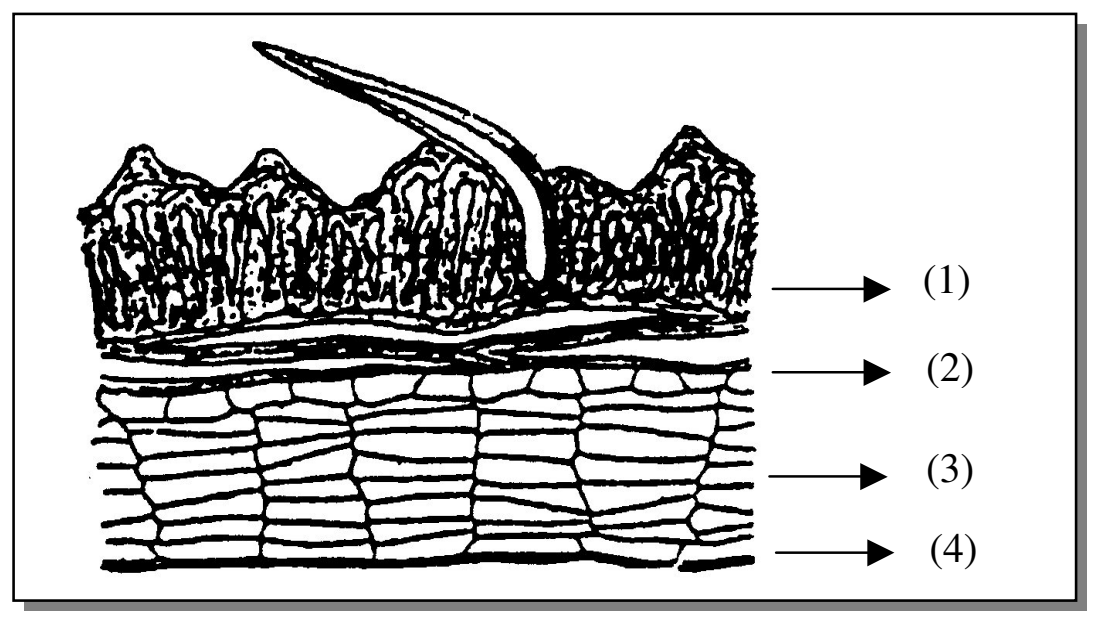

FIGURA 4 - Secção longitudinal da casca de arroz mostrando: (1) epiderme externa, (2) fibra esclerênquima, (3) célula parênquima e (4) epiderme interna ${ }^{[28,29]}$

Acredita-se que a sílica da casca de arroz exista na forma opalina (a opala é uma fase hidro-amorfa da sílica). A absorção de Si pelas plantas da solução do solo dá-se de forma passiva, com o elemento acompanhando o fluxo de massa da água que penetra nas raízes como ácido monossilícico $\left(\mathrm{H}_{4} \mathrm{SiO}_{4}\right)$, o qual concentra-se na casca e no caule da planta por evaporação da água e, finalmente, se polimeriza para formar a membrana sílico-celulósica.

A produção total de arroz em casca no Brasil em 2007 foi da ordem de 11 milhões de toneladas e o estimado para 200812 milhões de toneladas segundo 0 Instituto Brasileiro de Geografia e Estatística (IBGE), sabendo que as cascas representam 20\% desse valor, a produção anual desse rejeito no Brasil é da ordem de 2,4 milhões de toneladas para 2008. Há alguns anos, quase todo esse material ia parar nas lavouras e fundo de rios, num descarte prejudicial e danoso ao meio 
ambiente. Na indústria do arroz tem-se, como subproduto mais volumoso, as cascas, as quais podem ser aproveitadas de diversas maneiras.

A geração de energia por meio da queima da CA é uma alternativa praticável do ponto de vista tecnológico, viável do ponto de vista econômico e ético do ponto de vista ecológico, uma vez que existe tecnologia para a conversão, a matéria-prima é abundante na região e todo $\mathrm{CO}_{2}$ produzido na queima pode voltar para o ciclo de carbono da biosfera terrestre.

O arroz vem da lavoura com 25 a 30\% de umidade, índice que varia com as condições de plantio e com a época do ano. A umidade precisa ser reduzida para 12 a $15 \%$ para que o arroz seja beneficiado e, no máximo a $13 \%$, para que seja armazenado. A secagem é feita com queima da casca e os gases de combustão são empregados como meio de aquecimento. Uma usina exclusivamente produtora de arroz branco não tem consumo de vapor de processo.

O poder calorífico superior, em base seca, da casca de arroz, é 15,84 GJ/t. O poder calorífico inferior, com umidade de $11 \%$, é de $12,96 \mathrm{GJ} / \mathrm{t}$, muito superior ao bagaço de cana-de-açúcar. Uma usina produtora de arroz parabolizado tem demanda de vapor na produção industrial, para o encharcamento do arroz, nas autoclaves, para a própria parbolização do grão e, em algumas indústrias, na secagem. Uma usina de beneficiamento de arroz recebe o arroz colhido, que é transportado com casca para a usina. Segundo dados técnicos, ao longo de um ano, aproximadamente $15 \%$ da casca produzida é destinada à secagem do arroz, atividade que ocorre principalmente no período de colheita (janeiro a abril).

A secagem se concentra nesses meses, consumindo $60 \%$ da casca recolhida. Estima-se que, de toda a casca produzida ao longo de um ano, apenas $50 \%$ podem ser utilizadas na produção de eletricidade, uma vez que, além dos $15 \%$ destinados à secagem, cerca de $35 \%$ estão disponíveis em pequenas indústrias.

A casca é um material de densidade muito baixa, sendo o transporte viabilizado apenas para frete de retorno. No Rio Grande do Sul, estado responsável por $51 \%$ da produção orizícola nacional, de $75 \mathrm{MW}$ a $95 \mathrm{MW}$ de energia poderiam ser gerados a partir da queima de 760 mil toneladas de casca que sobram da industrialização do arroz no estado a casca representa aproximadamente $20 \%$ do 
peso do grão. Se toda a produção gaúcha fosse beneficiada no Rio Grande do Sul, haveria a formação de mais de 1 milhão de toneladas de resíduo, que, queimado, poderia gerar de $109 \mathrm{MW}$ a $136 \mathrm{MW}$ de energia.

Na Figura 5 é mostrado o centro de produção de vapor a partir da queima da casca de arroz na Arrozeira Urbano, em São Gabriel/RS, com capacidade geradora de 2,2 MW de energia.

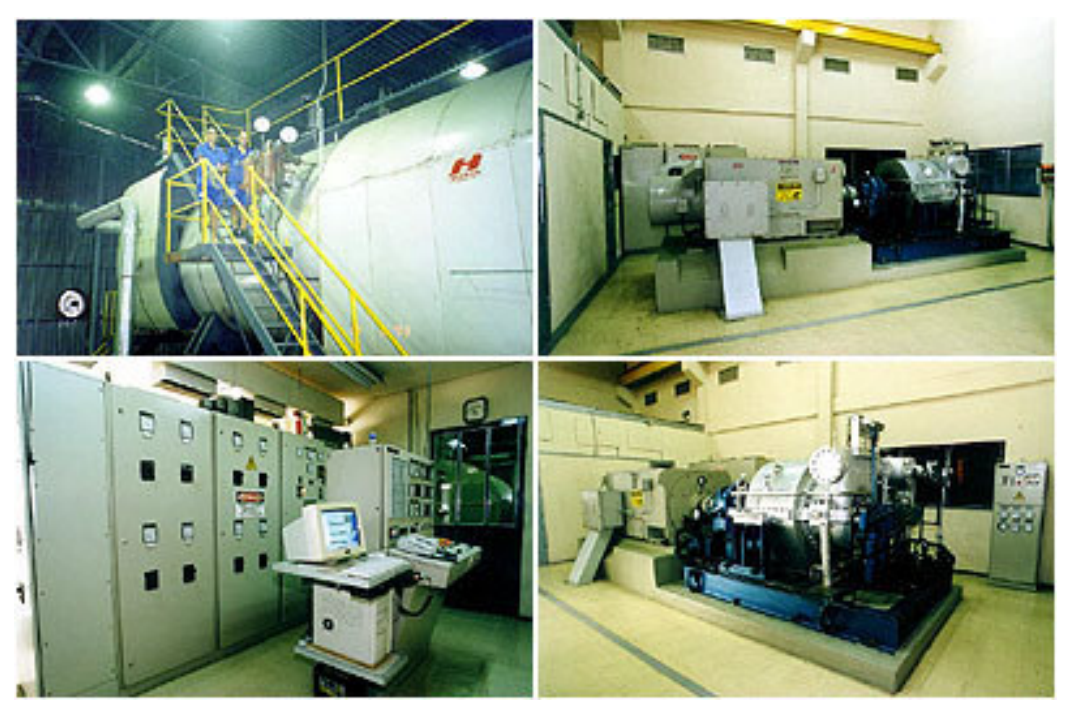

FIGURA 5 - Câmara de combustão da CA (caldeira), turbina, gerador e centro de controle da termoelétrica da Arrozeira Urbano

No caso da geração de energia pela combustão direta, o resíduo final é a cinza. Se ela for utilizada, direta ou indiretamente, para algum fim comercial, se fechará o ciclo da industrialização do arroz, sendo possível o total aproveitamento da matéria-prima proveniente da lavoura, já que farelo, gérmen e outras partes já têm seu destino no mercado. Afinal, uma produção industrial ideal é aquela que gera resíduo zero ${ }^{[30,31,32]}$.

Se toda a CA disponível no Brasil for queimada para geração de energia, a produção resultante, em termos de cinza pura, será de aproximadamente 434 mil toneladas ao ano (cerca de $18 \%$ do peso da casca) ${ }^{[33]}$. Por outro lado, se essa cinza for descartada no meio ambiente, provocará poluição, pois se sabe que a cinza 
gerada na combustão apresenta uma quantidade de carbono residual, o que é um grande poluente para o solo. Fica evidente que seu aproveitamento adequado resultará em benefício ao processo de conservação ambiental. Como a cinza contém alto teor de sílica ( 92\%), isto a torna um resíduo valorizado.

No entanto essa cinza só terá alto valor econômico se tiver qualidade alta, que é mensurada pela superfície específica alta, tamanho e pureza de partícula. Conseqüentemente, seria um grande desperdício de matéria-prima nobre jogá-la fora, já que pode ser usada em vários ramos industriais, tais como: eletrônica, construção civil, cerâmica, indústria química, fabricação de células fotovoltaicas, entre outros ${ }^{[34]}$.

\subsubsection{Aplicações da cinza da casca de arroz}

A escolha do uso apropriado da cinza da casca de arroz (CCA) depende de vários fatores. Os problemas específicos associados a estes fatores evidentemente diferem de país para país, de estado para estado dentro de um país, e de local para local dentro de um estado.

As principais considerações feitas incluem: problemas sócio-econômicos, quantidade, tipo e tamanho das fábricas; capacidade destas fábricas para determinar e avaliar o fornecimento de casca, o uso da casca em diferentes áreas e as quantidades envolvidas em tais usos; regularidade no fornecimento; transporte e estocagem necessários para a casca e os produtos; potencial de mercado para os produtos; relação econômica com a competição de materiais e produtos novos; possibilidades tecnológicas, função da tecnologia no desenvolvimento econômico e problema potencial de poluição ${ }^{[35]}$.

Diversos trabalhos têm sido publicadas utilizando a CCA. Citaremos alguns trabalhos na sequência:

* Pré-concentração de ouro, como adsorvente na substituição ao carbono ativado $^{[35] \text {; }}$

* obtenção de diferentes tipos de silicato como o tri(catecolato)silicato, glicolatos reativos, filmes flexíveis auto-suportados ${ }^{[35] \text {; }}$ 
* produção de carbeto de silício (SiC) para produção de cerâmicas resistentes e componentes de matrizes metálicas ${ }^{[35]}$;

* produção de sílica pura variando entre 99,5 a 99,66\% de $\mathrm{SiO}_{2}{ }^{[36]}$;

* na produção de concreto de alto desempenho a partir da sílica ativa ${ }^{[37]}$;

* na agricultura como substrato de origem mineral e orgânica para o cultivo de mudas ${ }^{[38]}$;

* produção de mulita $\left(3 \mathrm{Al}_{2} \mathrm{O}_{3}: 2 \mathrm{SiO}_{2}\right)$ que é um alumínio-silicato utilizado em produtos refratários e isolantes ${ }^{[39,40]}$;

* na vulcanização de borracha natural aumentando a velocidade de reticulação e diminuindo a energia de ativação aparente ${ }^{[41]}$.

A combustão da CA gera cinzas com formas estruturais variáveis (amorfa e/ou cristalina) que dependem tanto do tipo de equipamento e queima usado (processo artesanal a céu aberto, grelhas, processo industrializado por leito fluidizado com ou sem controle da temperatura), como do tempo e da temperatura de queima. A CA queimada em condições controladas (temperatura máxima de $1000^{\circ} \mathrm{C}$ ), ao atingir $800^{\circ} \mathrm{C}$ com um patamar de queima de duas horas, gera cinza residual constituída de sílica em forma cristalina de quartzo. Para temperaturas no intervalo de 450 a $700^{\circ} \mathrm{C}$, com patamar de três a quatro horas, obtem-se sílica no estado amorfo.

Quando a cinza está na forma amorfa, a mesma não apresenta riscos à saúde; porém, quando a cinza contém sílica na forma cristalina, esta se torna menos reativa e assim é considerada prejudicial à saúde humana. As cinzas oriundas de cascas queimadas a $400^{\circ} \mathrm{C}$ possuem área de superfície específica em torno de 147 $\mathrm{m}^{2} / \mathrm{g}$, quando queimadas a $800^{\circ} \mathrm{C}$ possuem área de superfície específica de $5 \mathrm{~m}^{2} / \mathrm{g} \mathrm{e}$ acima de $900^{\circ} \mathrm{C}$ o valor oscila entre 0,8 e $0,4 \mathrm{~m}^{2} / \mathrm{g}^{[34]}$.

A tendência ao decréscimo da área de superfície específica com o aumento da temperatura está relacionada com o fato da superfície das partículas sofrerem fusão e agregarem-se umas às outras.

A sílica amorfa é um material de fácil moagem e, quando moída é altamente reagente. Suas propriedades principais são a baixa condutividade térmica e a elevada resistência ao choque térmico. Desta forma é um componente desejável na 
composição de produtos cerâmicos como refratários e isolantes térmicos, que sofrerão intensa ação do calor e variação brusca de temperatura. E, por serem amorfos não são prejudiciais à saúde ${ }^{[28,42]}$.

Na Figura 6 é mostrada uma micrografia feita por microscopia eletrônica de varredura de uma seção transversal de uma partícula de cinza de casca de arroz.

A micrografia foi feita a partir de uma amostra de cinza de casca de arroz produzida em laboratório em combustão controlada e com extremo cuidado no manuseio para se preservar a estrutura silicosa da casca.

$\mathrm{Na}$ parte superior da Figura 6, uma epiderme corrugada e densa é claramente visível. Observa-se, logo abaixo, uma estrutura em tubos e depois o parênquima, estrutura celular com paredes muito finas ${ }^{[35,37]}$.

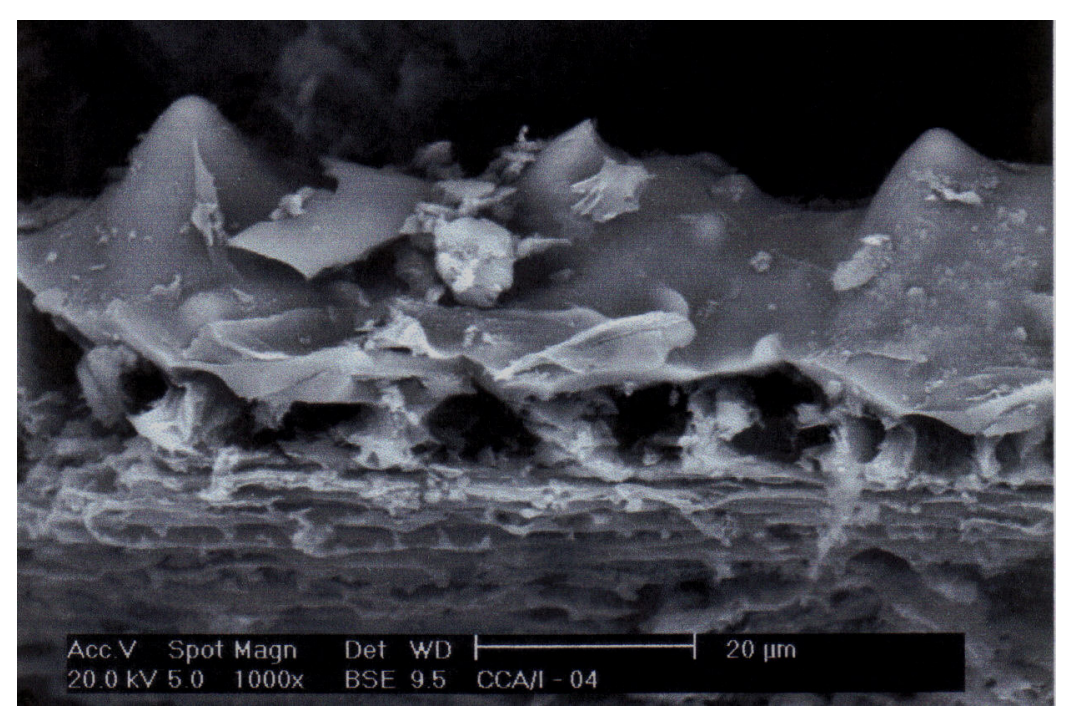

FIGURA 6 - Micrografia feita em MEV de cinza de casca de arroz onde se pode observar a estrutura original de sílica amorfa $(1000 x)^{[35]}$

A CCA utilizada neste trabalho é proveniente do beneficiamento de uma grande produtora de arroz em São Borja/RS, que desenvolveu juntamente com um empresário local um aglomerado de casca de arroz chamado briquete, que possui formato de lenha e é queimado em uma termoelétrica para a geração de energia elétrica. A temperatura gerada por esta queima é de aproximadamente 450 a $500^{\circ} \mathrm{C}$ 
por 4 horas, gerando a cinza que é diariamente retirada do forno pela empresa Intersílica e micronizada com tamanho médio de partículas de $4 \mu \mathrm{m}$ e resíduo em malha de 325 mesh < 1\%, com densidade de $2,18 \mathrm{~g} / \mathrm{cm}^{3}, \mathrm{pH}$ de 8 a 10 predominantemente amorfa e com produção de $35 \mathrm{t} / \mathrm{dia}^{[43]}$.

Estão sendo construídas mais 3 usinas termoelétricas na região de Uruguaiana, RS (municípios de São Borja, Dom Pedrito e São Sapé) que utilizará briquetes feitos a partir da casca de arroz para geração de energia, elevando a produção de CCA. Estima-se que a produção de CCA crescerá na ordem de 4.000 $\mathrm{t} / \mathrm{mês}^{[43]}$.

O carbono livre proveniente da combustão incompleta da casca de arroz máximo é de $8 \%$ conferindo cor preta à cinza com teor de umidade não superior a $1 \%{ }^{[43]}$. Essa coloração quando utilizada em grandes concentrações na formulação de plásticos, de 20 a 40\%, que são as concentrações usuais, confere uma cor negra ao polímero que evita a adição de pigmentação como o negro de fumo ou negrosina para tingir o material.

\subsubsection{Obtenção da CCA}

O processo de queima da casca de arroz inteira é realizado em duas etapas. $\mathrm{Na}$ primeira etapa, a casca é aquecida a uma temperatura entre 300 e $350^{\circ} \mathrm{C}$, e é mantida assim por 40 minutos para a volatização de toda água e hidrocarbonetos. Só após a eliminação de todos os voláteis, a temperatura é elevada a $600^{\circ} \mathrm{C}$ por uma hora ou até completar-se a combustão. Assim, obtém-se uma cinza de cor cinza clara com alta reatividade.

A cor dessa cinza pode variar para uma cor mais escura dependendo da quantidade de matéria orgânica (carbono) presente. Após o tratamento térmico para redução da matéria orgânica presente na CA a cinza é moída para reduzir o tamanho das partículas e aumentar a área de superfície específica ${ }^{[35,42]}$.

A CCA utilizada é a Microsílica MS-325 comercializada pela empresa Intersílica com sede em São Borja RS, que comercializa essa sílica para compostos de borracha. Esta empresa está fazendo parceria para o desenvolvimento desta 
sílica para náilon, que possui cor preta, com carbono livre máximo de $8 \%$, proveniente da combustão incompleta da casca de arroz ${ }^{[43]}$. Como normalmente a grande utilização de compostos com carga mineral é de cor preta, é uma vantagem utilizar uma cinza desta cor porque na injeção são evitadas as marcas de fluxo geralmente deixadas pelo talco que é branco comprometendo o acabamento da peça. Outra vantagem é econômica por não ser necessário o tingimento do composto de PA $630 \%$ CCA com negro de fumo.

Nas fotografias de (a) até (f) da Figura 7 são mostradas as etapas do processo de incorporação da CCA como carga na PA 6.

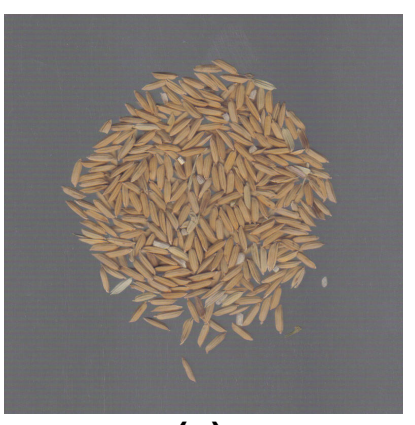

(a)

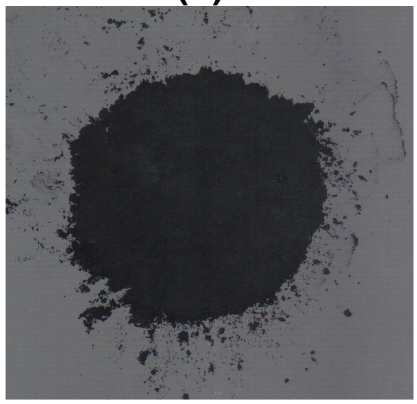

(d)

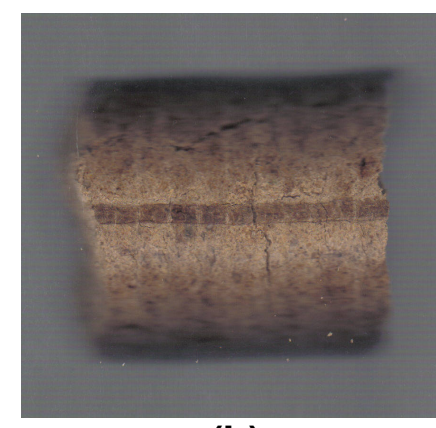

(b)

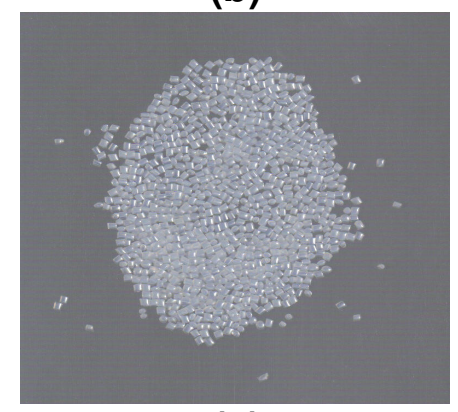

(e)

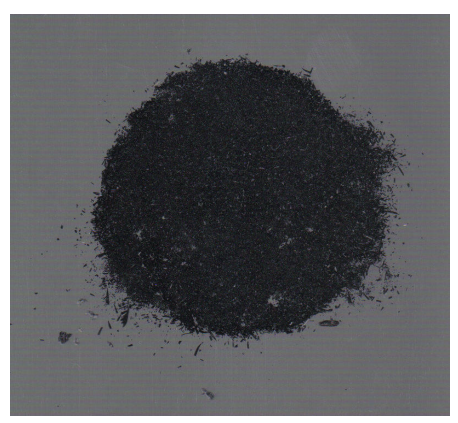

(c)

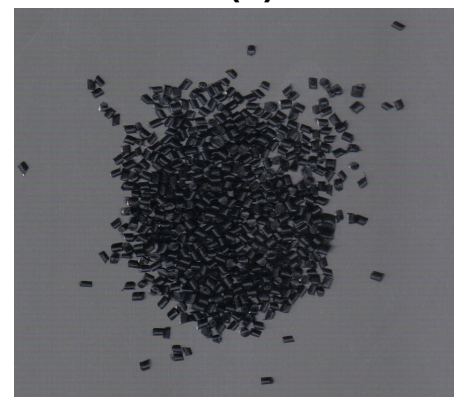

(f)

FIGURA 7 - Sequência de fotos que mostram as etapas de incorporação da CCA como carga na PA 6. Na imagem (a) tem-se o arroz a ser beneficiado, na (b) o aglomerado de casca de arroz chamado briquete, na (c) a cinza logo após a queima da casca, na (d) a cinza já micronizada, na (e) o polímero base e na (f) a CCA incorporada ao polímero base

\subsubsection{Composição química da CCA e do talco obtidos em literatura}

$\mathrm{Na}$ Tabela 4 são apresentados alguns valores obtidos de catálogo de produtores da matéria-prima talco e da $\mathrm{CCA}^{[25,28,30]}$. 

TABELA 4 - Composição química em percentagem em massa do talco e da
CCA obtidos da literatura

\begin{tabular}{ccc}
\hline \multicolumn{3}{c}{ Composição Química (\% em massa) } \\
\hline Compostos & Talco & CCA \\
\hline $\mathrm{SiO}_{2}$ & 58,0 & 89,7 \\
$\mathrm{Fe}_{2} \mathrm{O}_{3}$ & 0,9 & 0,5 \\
$\mathrm{CaO}$ & 0,4 & 1,1 \\
$\mathrm{MgO}$ & 31,0 & 2,0 \\
$\mathrm{~K}_{2} \mathrm{O}$ & 0,02 & 1,5 \\
$\mathrm{Na}_{2} \mathrm{O}$ & 0,04 & 1,6 \\
$\mathrm{P}_{2} \mathrm{O}_{5}$ & - & 1,9 \\
$\mathrm{~S}$ & - & 0,9 \\
$\mathrm{Al}_{2} \mathrm{O}_{3}$ & 4,2 & - \\
$\mathrm{TiO}_{2}$ & 0,1 & - \\
${ }^{*} \mathrm{PF}$ & $5,4 \%$ & 5,00 \\
\hline${ }^{*}$ Perda ao fogo $\left(1000^{\circ} \mathrm{C}\right)$ &
\end{tabular}

\subsection{Efeito da radiação ionizante em polímeros}

A radiação de energia alta produz ionização e excitação na molécula dos polímeros ${ }^{[23]}$. Estas energias ao interagirem com moléculas poliméricas, provocam dissociação, reações de adição e de decomposição que conduzem a uma mudança química na estrutura do polímero ${ }^{[5]}$.

A cisão e a reticulação na molécula do polímero com formação de pequenas moléculas e modificação na sua estrutura química, respectivamente, são responsáveis pelas mudanças nas propriedades do material. O entendimento dessas mudanças na estrutura do polímero em relação às doses de radiação aplicadas é de fundamental importância para aplicações práticas ${ }^{[10,44]}$.

O conhecimento da degradação química de polímeros por radiação tem crescido bastante devido à utilização de materiais poliméricos em uma grande variedade de aplicações submetidas às radiações ambientais, às radiações para esterilização de equipamentos médicos e alimentícios e no desenvolvimento de processos de radiação para mudança de propriedades de materiais poliméricos ${ }^{[4,5,45]}$. 
Os efeitos da radiação em polímeros é resultado de uma sequência de eventos que podem ser divididos em ${ }^{[5]}$ :

* físico: energia absorvida e transferida;

* físico-químico: ionização e excitação;

* químico: radicais, moléculas ionizadas, reações radical-radical e reações iônicas.

Essa sequência de eventos provoca mudanças morfológicas e estruturais nas propriedades dos materiais.

Nos processos de interação da energia com a matéria, as radiações ionizantes perdem a sua energia principalmente pela interação com os elétrons orbitais das moléculas localizadas ao longo da sua trajetória, originando estados excitados ou ionizando-as e gerando radicais livres ou íons.

Uma molécula pode ser ionizada quando uma quantidade de energia transferida, proveniente da partícula incidente, levando consigo uma carga positiva, isto é, ionizando a molécula ${ }^{[46,47]}$.

Quando a quantidade de energia transferida, proveniente da partícula incidente, é menor que o potencial de ionização da molécula, podem ocorrer excitações eletrônicas, levando um elétron de seu estado de menor energia (estado fundamental) para um estado de maior energia, tornando a molécula instável e reativa quimicamente.

A quantidade de energia absorvida pela matéria em virtude da interação com a radiação ionizante pode ser medida diretamente e o rendimento da química das radiações é expresso em termos de um valor $G$, o qual representa o número de moléculas modificadas ou formadas por $100 \mathrm{eV}$ de energia absorvida.

As moléculas poliméricas quando são irradiadas, ( $M \longrightarrow$ radiação), liberam elétrons de energia alta e provocam ionização da molécula ${ }^{[5,44,45]}$.

$$
\mathrm{MM} \leadsto \mathrm{MM}^{+}+\mathrm{e}^{-}
$$

O elétron primário causa ionização de outras moléculas produzindo mais elétrons. 


$$
\mathrm{e}^{-}+\mathrm{MM} \longrightarrow \mathrm{MM}^{+}+2 \mathrm{e}^{-}
$$

A atração Coulombiana produz íons carregados positivamente que desaparecem rapidamente ao combinarem com elétrons. Isto produz um estado eletrônico altamente excitado.

$$
\mathrm{MM}^{+}+\mathrm{e}^{-} \longrightarrow \mathrm{MM}^{*}
$$

Uma parte das interações da radiação com o material polimérico pode também resultar apenas em transferência de energia que é insuficiente para causar ionização, mas resulta diretamente em um estado eletronicamente excitado.

$\mathrm{MM}$

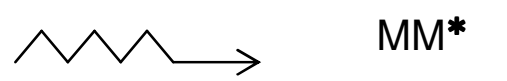

Estas moléculas que se encontram no estado excitado decaem para o estado fundamental, emitindo fosforescência e fluorescência, ou por meio de reações químicas, por quebra das ligações heterolíticas produzindo íons, ou por quebra das ligações homolíticas, favorecendo a formação de radicais que interagem entre si provocando a reticulação das moléculas.
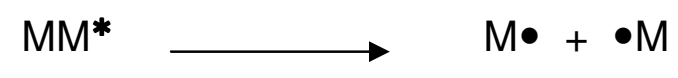

O processo de reticulação introduz ligações cruzadas, ou seja, ligações entre moléculas lineares produzindo polímeros tridimensionais com massa molar numérica $\left(\mathrm{M}_{\mathrm{n}}\right)$ alta. Com o aumento da reticulação, aumenta o intercruzamento entre as moléculas e a estrutura do polímero se torna mais rígida. As propriedades dos polímeros após a reticulação dependem muito pouco da estrutura química, mas se tornam função da densidade de reticulação na estrutura molecular. Uma das propriedades básicas desta estrutura molecular intercruzada é o decréscimo da solubilidade ${ }^{[4]}$. Em estudos feitos por Deeley, Woodward e Sauer cujo trabalho foi citado por Kircher e Bowman ${ }^{[45]}$, foi mostrado que a reticulação da poliamida quando 
irradiada, não é proporcional à dose. A reticulação para a poliamida 6.6 parece saturar quando chega ao redor dos $10 \%$, indicando que as cisões da cadeia passam a ter papel relevante. A grandeza "dose absorvida" abrange todos os tipos de radiação ionizante e é válida para qualquer tipo de material absorvedor.

A dose absorvida é definida como a quantidade de energia depositada (transferida) pela radiação ionizante na matéria num determinado volume, dividida pela massa contida nesse volume, assim sendo, pode-se definir a dose absorvida pelo material segundo a equação $8^{[4,5,44]}$ :

$$
D=d E / d m
$$

Em estudos realizados por Little, citado no trabalho de Kircher e Bowman ${ }^{[45]}$, foi constatado que a fibra de poliamida rapidamente perde resistência quando irradiada na presença de ar, entretanto, esse problema pode ser contornado aditivando o polímero com antioxidante. As propriedades dos materiais poliméricos são afetadas pela radiação como resultado das mudanças químicas na molécula do polímero, provocando mudanças na massa molar e na estrutura do material.

A degradação do polímero é freqüentemente relacionada com a redução da massa molar, ou no decréscimo de algumas propriedades desejadas, mas estas não são definições necessariamente fechadas, pois um aumento na reticulação pode ser benéfico em uma aplicação, mas se acompanhada de um decréscimo na resistência à ruptura pode ser uma desvantagem em outra aplicação. Portanto, é apropriado considerar que a degradação é alguma mudança molecular, na morfologia ou nas propriedades do material do polímero irradiado.

De um modo geral, a degradação consiste na cisão de ligações na cadeia principal e não é o mesmo que despolimerização e pode ser considerado um processo que ocorre ao acaso. Como resultado da radiação em alguns polímeros ocorre preferencialmente a degradação a reticulação. O efeito da degradação é o decréscimo da massa molar e a formação de produtos com massa molar baixa gerados pela fragmentação da cadeia, neste caso pouco ou nenhum monômero é formado ${ }^{[45,48]}$. 


\subsubsection{Reticulação e cisão}

Exceto em alguns poucos casos aonde a cisão da cadeia principal é um processo exclusivo, alterando o tamanho da cadeia, os polímeros lineares sofrem os dois processos, reticulação e cisão da cadeia principal quando expostos à radiação de energia alta.

Por via de regra, os polímeros com carbono tetrasubstituído na unidade de repetição, sofrem predominantemente ruptura na cadeia principal, indicando um decréscimo na massa molar com o aumento da dose absorvida.

A determinação da radiação química produzida na cisão $G(S)$ e reticulação $G(X)$ da cadeia principal (o valor de $G$ é o número de moléculas ou átomos produzidos ou decompostos por $100 \mathrm{eV}$ de energia absorvida, $G(S)$ e $G(X)$ designam o número de ligações quebradas e novamente formadas, intermolecularmente, na cadeia principal por $100 \mathrm{eV}$, respectivamente) é relativamente fácil, se a distribuição da massa molar (MWD) inicial for do tipo mais provável.

Os polímeros sintéticos, normalmente consistem de uma mistura de macromoléculas quimicamente idênticas de diferentes tamanhos. $O$ tamanho molecular ou distribuição da massa molar (MWD), são importantes propriedades que caracterizam um polímero. Freqüentemente o MWD é alterado com a ruptura ou reticulação da cadeia principal.

Neste caso, o grau médio da massa molar de polimerização $u_{1}$ e $u_{2}$, respectivamente, depende da dose absorvida $D(\mathrm{em} \mathrm{eV/g})$ de acordo com as equações 9 e 10:

$$
\begin{aligned}
& \frac{1}{u_{1}}=\frac{1}{u_{1,0}}+[G(S)-G(X)] \frac{D m}{100 N_{A}} \\
& \frac{1}{u_{2}}=\frac{1}{u_{2,0}}+\left[\frac{G(S)}{2}-2 G(X)\right] \frac{D m}{100 N_{A}}
\end{aligned}
$$


em que, $N_{A}=$ número de Avogrado;

$m=$ massa molar da estrutura da unidade de repetição.

Deve-se notar que a Eq. 9 pode ser aplicada para qualquer MWD inicial.

Os valores $G(S)$ e $G(X)$ podem ser determinados pelos valores de $u_{1}$ e $u_{2}$ em função da dose absorvida. Se predominar a reticulação, o polímero se torna insolúvel e $D>D_{\text {gel. }} G(S)$ e $G(X)$ também podem ser determinados com a ajuda da equação 9 de Charlesby-Pinner:

$$
s+s^{1 / 2}=\frac{G(S)}{2 G(X)}+\frac{100 N_{A}}{u_{2,0} G(X) m D}
$$

em que, $s$ representa a fração insolúvel. Esta equação é aplicada somente para reticulação e cisão aleatórias da cadeia principal para a mais provável MWD inicial.

$\mathrm{Na}$ Tabela 5 são apresentados os valores de $G(S)$ e $G(X)$ determinados com a ajuda dos métodos descritos anteriormente e o processo predominante por efeito da radiação em diferentes tipos de polímeros ${ }^{[9]}$.

TABELA 5 - Polímeros submetidos à radiação química com cisão e reticulação da cadeia principal, irradiados com baixo LET (Transferência Linear de Energia), à temperatura ambiente, sob vácuo ou na presença de gás inerte

\begin{tabular}{lccc}
\hline \multicolumn{1}{c}{ Polímero } & $G(S)$ & $G(X)$ & Processo predominante \\
\hline Polietileno & $-x-$ & 2,0 & reticulação \\
Poliisobuteno & $1,5-5,0$ & $<0,05$ & cisão \\
Poliestireno & 0,02 & 0,03 & reticulação \\
Poli (metacrilato de metila) & $1,2-2,6$ & $-x-$ & cisão \\
Politetrafluoroetileno & $0,1-0,2$ & $-x-$ & cisão \\
Celulose & $3,3-6,8$ & $-x-$ & cisão \\
\hline
\end{tabular}




\subsubsection{Aceleradores industriais de elétrons}

De um modo geral, em todos os tipos de aceleradores, os elétrons são produzidos em um cátodo aquecido mantido em uma região de potencial mais elevado. Esses elétrons são acelerados então, por uma diferença de potencial aplicada entre o cátodo e o ânodo. Assim, os elétrons adquirem energia suficiente para atravessar a janela de saída que, em geral, é constituída de uma folha fina de titânio com espessuras entre 20 a $40 \mu \mathrm{m}$.

Esse material apresenta resistência mecânica suficiente para suportar a pressão atmosférica do exterior. Toda a região de produção e aceleração dos elétrons deve ser mantida em alto vácuo para permitir que a focalização e a aceleração do feixe em direção à janela sejam adequadas.

Os aceleradores de elétrons são utilizados em uma ampla gama de aplicações industriais tais como a irradiação de fios e cabos elétricos, desinfestação de alimentos e esterilização de materiais cirúrgicos, reticulação de borracha, cura de resinas entre outras ${ }^{[6,49,50]}$.

\subsubsection{Irradiação de poliamida}

As pressões do mercado para o aumento de produção e redução de custos sem perda de qualidade conferem aos materiais plásticos, quer sejam commodities ou plásticos de engenharia, uma vantagem enorme quando comparados a outros materiais.

No momento, as empresas estão mudando um pouco seu foco na polimerização de novos materiais plásticos para atuar fortemente na sua modificação por meio de blendas (combinação de um ou mais plásticos diferentes por processos físicos) para atingir as exigências de mercado.

Diante desse quadro, a utilização da radiação ionizante, tem um relevante papel tanto na modificação como na polimerização dos polímeros ${ }^{[50]}$.

Atualmente, como já foi mencionado anteriormente, dentre os plásticos de engenharia, a poliamida 6 vem se destacando pela sua resistência química, térmica 
ou mecânica e periodicamente são encontradas novas aplicações para essa classe de materiais por isso é premente a pesquisa da radiação ionizante nessa área.

As pesquisas sobre os efeitos da radiação ionizante em poliamidas estão muito voltadas para o estudo da poliamida $6 \mathrm{em}$ fibras (produtos têxteis como tecidos e carpetes) e filmes (embalagens alimentícias), pois por questões mercadológicas o grande consumo mundial está voltado para esse tipo de poliamida.

Testes realizados com poliamida em forma de filme mostraram que o limite máximo de dose absorvida sem perda de características foi de 8,8 kGy, e quando irradiada a 47 kGy perdeu $25 \%$ de suas características mecâncias, porém, teve um aumento de $25 \%$ na sua resistência à tração em doses acima de $1000 \mathrm{kGy}$. Em contraste a isso, o polímero orientado, fibra de poliamida, não mostrou aumento na resistência à tração ${ }^{[45]}$.

Em dose de $85 \mathrm{kGy}$, a fibra de poliamida irradiada em ar, teve uma perda superior a $50 \%$ na sua resistência original. A possível explicação para esse fato pode ser atribuída à diferença na cristalinidade da poliamida em fibra em relação à poliamida em forma de filme. Outra explicação pode ser a presença do efeito do oxigênio na poliamida ${ }^{[45]}$.

Embora a resistência à tração da poliamida aumentou 25\% em doses acima de $1000 \mathrm{kGy}$, o alongamento caiu muito rapidamente tendo chegado a $25 \%$ de perda em doses próximas a 50 kGy. A resistência ao impacto caiu aproximadamente na mesma proporção que o alongamento.

A reticulação da poliamida quando irradiada não é proporcional à dose. $A$ reticulação da poliamida 6.6 aparentemente satura as ligações cruzadas ao redor de $10 \%$, indicando que a cisão da cadeia a partir desse ponto, passa a ter papel importante no processo.

Little e Born afirmam em trabalho citado por Kircher e Bowman ${ }^{[45]}$ que a poliamida irradiada na presença de ar perde rapidamente resistência, porém, podese contornar esse problema com a adição de antioxidantes na formulação do polímero. 


\subsection{Caracterização de polímeros}

A caracterização dos polímeros tem por finalidade medir as propriedades físico-químicas do material irradiado, por meio de ensaios regulamentados por normas internacionais, que norteiam as mudanças ocorridas no material objeto desta pesquisa quando comparados com as do polímero sem irradiar.

\subsubsection{Resistência à tração, módulo de elasticidade e alongamento à ruptura}

A resistência à tração é uma das mais importantes indicações das características físicas de um material e é a propriedade mais usualmente especificada para materiais plásticos. Diferentes tipos de plásticos são comparados em base a este tipo de resistência. Muitos plásticos são muito sensíveis a este tipo de força quando expostos ao meio ambiente. Por essa razão, os resultados obtidos por esse método, não podem ser considerados válidos para aplicações envolvendo materiais sujeitos a tensões constantes em diferentes condições ambientais.

As propriedades de tração são utilizadas para selecionar preferencialmente, um determinado material plástico, de um amplo grupo, destinado a uma aplicação específica, que leva em conta todas as limitações previstas pelo desenho do produto.

A resistência à tração, de um modo geral, é a medida da capacidade de um material resistir à forças que tendem puxar e separá-lo e determinar o quanto ele estende antes da ruptura. A resistência à tração é avaliada pela carga aplicada ao material, por unidade de área, no momento da ruptura ${ }^{[51,52]}$.

O módulo de elasticidade transmite os limites de tensão suportado por uma peça em uso sem que ela seja permanentemente deformada e é medida na região elástica da curva tensão $(\sigma) \mathrm{em} \mathrm{kgf} / \mathrm{cm}^{2}$ pelo alongamento $(\varepsilon)$ em porcentagem. $O$ módulo de elasticidade é medido pela razão entre a tensão aplicada e a deformação resultante, dentro do limite elástico, em que a deformação é totalmente reversível e proporcional à tensão. Na curva de tensão em função da deformação é mostrada uma região aproximadamente linear no seu início ${ }^{[53]}$.

Nestas regiões cada deformação é reversível e o material é perfeitamente 
elástico e retorna completamente ao seu formato original, após a retirada da carga aplicada, devido ao realinhamento das cadeias macromoleculares longas e flexíveis. Tensões posteriores podem acarretar escoamento macromolecular com 0 rompimento de ligações secundárias entre cadeias adjacentes, resultando em deformações permanentes. O coeficiente angular na região de linearidade é denominado módulo de elasticidade.

Alongamento é a medida da ductilidade de um material, determinada em um teste de tração. É o aumento no comprimento útil (medido após a ruptura) dividido pelo comprimento útil original. Um maior alongamento indica uma maior ductilidade. O alongamento não pode ser usado para prever o comportamento de materiais submetidos a cargas repentinas ou repetidas. É o alongamento percentual no momento imediatamente anterior à ruptura do corpo-de-prova ${ }^{[53]}$.

\subsubsection{Resistência ao impacto Charpy com e sem entalhe}

As propriedades de impacto dos materiais poliméricos estão diretamente relacionadas com a tenacidade dos materiais. Tenacidade é definida como a capacidade do polímero absorver a energia aplicada. Resistência ao impacto é uma medida de tenacidade. Quanto maior a resistência ao impacto de um material, maior é a sua tenacidade e vice-versa.

A resistência ao impacto, é a capacidade de um material resistir à quebra quando submetido ao choque de um peso, ou, a capacidade de resistir à fratura quando submetido a uma força aplicada em alta velocidade ${ }^{[51]}$.

A teoria que envolve tenacidade e fragilidade de um polímero é muito complexa e por essa razão de difícil entendimento. A flexibilidade molecular tem um importante papel em determinar a relativa fragilidade ou tenacidade do material. Por exemplo, em um polímero rígido como o poliestireno e o poli(metacrilato de metila), os segmentos moleculares são incapazes de se distenderem e responder à rápida aplicação de uma força mecânica e o impacto produz uma fragilidade na estrutura molecular.

Em contraste, polímeros flexíveis como os vinílicos plastificados, possuem 
resistência ao impacto alta devido à capacidade dos grandes segmentos moleculares se distenderem e responder rapidamente às forças mecânicas aplicadas ${ }^{[1,53,54]}$.

\subsubsection{Resistência à flexão e módulo de flexão}

Neste ensaio determina-se a resistência à flexão em corpos-de-prova moldados a partir de compostos plásticos. A resistência à flexão é a capacidade de um material resistir a forças aplicadas longitudinalmente e perpendicularmente ao seu eixo ${ }^{[53]}$.

Muitos polímeros não quebram quando submetidos as forças de flexão mesmo depois de uma grande deflexão o que faz com que seja impraticável a medida da ruptura à flexão para muitos polímeros. Nestes casos, a prática usual, é medir as forças de flexão até que a tensão máxima nas fibras da superfície externa do corpo-de-prova tenham alcançado $5 \%$.

Para materiais poliméricos que rompem facilmente sob forças de flexão, a espécie é submetida a deflexão até ocorrer a ruptura das fibras externas ${ }^{[51,52]}$.

Módulo de flexão é a relação entre a tensão máxima das fibras e a deformação máxima, dentro do limite elástico do diagrama de tensão pela deformação obtido em um teste de flexão ${ }^{[51,53,54]}$.

\subsubsection{Resistência ao impacto por queda de dardo}

Esse ensaio mede a energia gasta por uma massa padrão, solta de uma altura predeterminada, para deformar significativamente um corpo-de-prova ${ }^{[55]}$.

\subsubsection{Análise de teor de carga}

Esta análise tem por objetivo determinar o teor de carga ou reforços em polímeros por diferença de peso da amostra calcinada em mufla de microondas ou mufla de resistência e o resultado é apresentado em porcentagem de peso ${ }^{[56]}$. 


\subsubsection{Densidade}

Densidade é a relação entre a massa em gramas de um polímero e o seu volume em centímetros cúbicos determinado em picnômetro a $23^{\circ} \mathrm{C}$ baseado na norma ISO 1183. O corpo-de-prova deve ser obtido diretamente da peça moldada e deve ter menos de $1 \mathrm{~cm}^{3}$ de volume. Não pode ter superfície rugosa, com impurezas ou gorduras e não ter reentrâncias ou regiões puntiformes. A densidade pode indicar o grau de uniformidade na moldagem de um produto. Mudanças na densidade pode significar variação na cristalinidade, perda de plastificante ou outros aditivos por degradação ou absorção de solventes ou umidade ${ }^{[53]}$.

\subsubsection{Resistência ao fio incandescente}

Neste ensaio determina-se a resistência ao calor anormal. Este ensaio simula a resistência do material plástico em uma situação de curto circuito elétrico em três temperaturas: 750,850 e $960^{\circ} \mathrm{C}$ por meio do contato de uma fonte intensa de calor (resistência) em contato com o corpo-de-prova ${ }^{[57]}$.

\subsubsection{Calorimetria exploratória diferencial (DSC)}

A Calorimetria Exploratória Diferencial (DSC) é uma técnica de análise térmica usada para determinar mudanças físicas ou químicas que são acompanhadas de ganho ou perda de calor.

Esta técnica mede a absorção de energia na forma de calor (processo endotérmico) ou a evolução (processo exotérmico) por uma amostra, em calorias, e a sua mudança de temperatura ${ }^{[55]}$.

A temperatura de fusão de um polímero depende do grau de cristalinidade e do tipo da estrutura cristalina. A temperatura de fusão cristalina $\left(T_{m}\right)$, é teoricamente, a temperatura mais alta na qual os cristais poliméricos podem existir.

A definição dessa temperatura só tem significado para materiais altamente cristalinos, como as poliamidas, e é obtida com a decomposição da estrutura 
cristalina $^{[52,55]}$.

No caso de polímeros com baixo grau de cristalinidade, o processo de fusão se estende sobre uma estreita faixa de temperatura. Nesse caso não se tem a temperatura de fusão, mas sim, uma "faixa" ou "intervalo" de fusão.

A poliamida 6 por ser alifática linear e por ter grupos amidas polares espaçados regularmente, cristalizam com atração intermolecular alta ${ }^{[14,54]}$.

A atração intermolecular alta gera polímeros com alta temperatura de fusão, portanto, havendo alterações na estrutura da molécula é de se esperar alterações na sua temperatura de fusão.

A caracterização de polímeros pela técnica de DSC é empregada na determinação qualitativa e quantitativa de transições de fase, como a temperatura de transição vítrea, temperatura de fusão, grau de cristalização, estudo da cinética de polimerização, de decomposição, de cura, porcentagem de aditivos em polímeros, estabilidade térmica e oxidativa e grau de reticulação ${ }^{[58,59]}$.

\subsubsection{Temperatura de amolecimento Vicat}

Este teste tem por objetivo estabelecer um parâmetro para avaliar a resistência térmica de materiais termoplásticos conforme norma ISO 527 . É a temperatura na qual uma agulha de seção transversal circular com área igual a 1 $\mathrm{mm}^{2}$ penetra $1 \mathrm{~mm}$ de profundidade em um corpo-de-prova de material termoplástico sob carga específica (geralmente $1 \mathrm{~kg}$ ) e utilizando uma velocidade de aquecimento pré-determinada. Os dados obtidos a partir deste teste podem ser usados para comparar a resistência térmica (ou ponto de amolecimento) de materiais termoplásticos ${ }^{[53]}$.

\subsection{Caracterização da CCA}

\subsubsection{Espectrometria de fluorescência de Raio X (FRX)}

O espectrômetro de fluorescência de raios $X$ é um instrumento que determina quantitativamente os elementos presentes em uma determinada amostra. 
Isto é possível por meio da aplicação de raios $X$ na superfície da amostra e a posterior análise dos raios $X$ fluorescentes emitidos. A técnica de fluorescência de raios $X$ é não-destrutiva para todos os tipos de amostras, incluindo sólidos, líquidos, pó e discos. Desta forma, a técnica de fluorescência de raios $X$ é utilizada para pesquisa e controle de qualidade em uma ampla área de atuação como nas petroquímicas, em indústrias farmacêuticas, metalúrgica, mineração, cimento, entre outras.

A FRX pode ser classificada como uma técnica de emissão atômica, fundamentada no efeito fotoelétrico. Quando um átomo é submetido a um processo de irradiação utilizando-se uma fonte de raios $X$ (tubo de raios $X$, indução por partícula, radioisotópos naturais, luz síncrotron, entre outros), um elétron pode ser ejetado das camadas eletrônicas mais internas (efeito fotoelétrico). Para estabilização desta forma excitada, elétrons das camadas eletrônicas mais externas caem rapidamente para as vacâncias geradas, liberando a diferença de energia (DE) existente entre os dois níveis de energia envolvidos. Como este processo envolve níveis de energia que são característicos de cada elemento, a radiação emitida para cada transição é também característica. Desta maneira, a energia da radiação emitida pode ser diretamente utilizada na identificação da espécie em questão. Por outro lado, como a intensidade da radiação emitida é diretamente proporcional à concentração da espécie, a técnica também fornece informações que podem ser utilizadas para fins quantitativos ${ }^{[60,61]}$. 


\section{MATERIAIS E MÉTODOS}

\subsection{Matéria-prima utilizada}

Para a execução desse trabalho, utilizaram-se corpos-de-prova injetados de poliamida $630 \%$ CM preto com densidade de $1,30 \mathrm{~g} / \mathrm{cm}^{3}$ e PA $630 \%$ CCA preto com densidade de $1,30 \mathrm{~g} / \mathrm{cm}^{3}$, isentas de aditivos de proteção UV, antioxidantes ou termoestabilizantes, fornecidos pela Radici Plastics Ltda..

Os corpos-de-prova foram injetados em uma máquina injetora Batenfeld, modelo TM 1000/25, comando Unilog B2 de 100 t de fechamento.

\subsection{Caracterização das amostras}

Os ensaios foram realizados em duas etapas.

$\mathrm{Na}$ primeira etapa, realizou-se a caracterização do polímero não irradiado, determinando-se as propriedades mecânicas e térmicas.

$\mathrm{Na}$ segunda etapa, irradiou-se os corpos-de-prova da PA $630 \%$ CCA com doses de 200, 300 e $400 \mathrm{kGy}$ a uma taxa de dose de 22,38 kGy/s em um acelerador de elétrons industrial tipo JOB 188 de energia de 0,5 a 1,5 MeV e corrente de 0,1 a $25 \mathrm{~mA}$, do Centro de Tecnologia das Radiações do IPEN - CNEN/SP, e determinaram-se as propriedades mecânicas e térmicas dos polímeros irradiados.

Foi também irradiada diretamente a CCA com doses de 50, 100 e 150 kGy, porém não conseguiu-se extrudar a PA 6 com a CCA irradiada nas doses citadas porque a rosca da extrusora travava constantemente, inviabilizando a sua produção, portanto esta alternativa foi descartada.

Na Figura 8 é mostrado o sistema de varredura de um acelerador de elétrons industrial tipo JOB 108 utilizado no presente trabalho. 


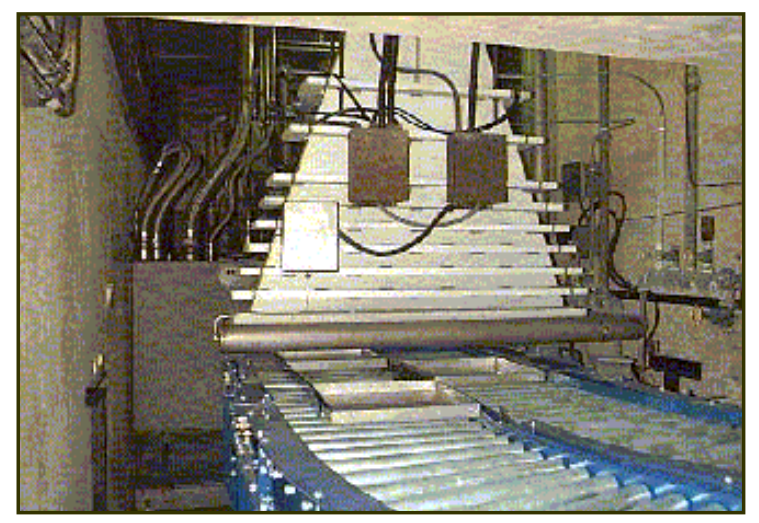

FIGURA 8 - Sistema de feixe de varredura do acelerador de elétrons do Centro de Tecnologia das Radiações do IPEN

Os ensaios mecânicos e térmicos foram realizados no laboratório de Controle de Qualidade da Radici Plastics Ltda..

A caracterização da CCA por fluorescência de Raios $X$ foi realizado no laboratório da Votorantin Cimentos localizado na cidade de Curitiba, Paraná.

As propriedades mecânicas, térmicas e químicas analisadas foram:

* espectrometria de fluorescência de Raios X (FRX);

* densidade seguindo a norma ISO 1183;

* teor de carga seguindo a norma ISO 3451/4;

* resistência ao impacto Charpy com entalhe seguindo a norma ISO 179;

* resistência ao impacto Charpy sem entalhe seguindo a norma ISO 179;

* resistência ao impacto por queda livre seguindo norma Radici/Bosch;

* resistência à tração seguindo a norma ISO 527;

* alongamento a ruptura seguindo a norma ISO R527;

* resistência à flexão seguindo a norma ISO 178;

* módulo de flexão seguindo a norma ISO 178;

* módulo de elasticidade seguindo a norma ISO 527;

* temperatura de fusão por DSC;

* fio Incandescente de acordo com a norma NBR 6272/1980 (750ํㄷ, 850ํㅡ e $960^{\circ} \mathrm{C}$ ) com corpos-de-prova de $3,00 \mathrm{~mm}$ de espessura;

* temperatura de amolecimento Vicat seguindo a norma ISO 306; 
* teste de aderência em corte de grade, norma ISO 2409 e teste de aderência por batida de pedra, norma DIN 50014, em peças pintadas.

\subsection{Caracterização da PA $630 \%$ CM (talco e CCA)}

Como neste trabalho foram realizados ensaios térmicos, físicos e químicos pretende-se a continuação descrever os métodos de caracterização utilizados para estes tipos de ensaio.

\subsubsection{Resistência à tração, módulo de elasticidade e alongamento à ruptura}

Os ensaios de resistência à tração, módulo de elasticidade e alongamento à ruptura, foram executados em máquina universal de ensaios marca Instron.

Os corpos-de-prova irradiados e não irradiados para ambos os ensaios foram injetados de acordo com a norma ISO 527 e os ensaios foram realizados em estado de injeção, ou seja, com teor de umidade de $0,20 \%$ máximo chamados de corpos-deprova seco. $O$ controle dessa umidade foi feito por pesagem dos corpos-de-prova assim que eles sairam da injeção sem umidade.

Os ensaios foram realizados a $23^{\circ} \mathrm{C}$ e os resultados expressos pela média aritmética de três medições.

\subsubsection{Resistência ao impacto Charpy com e sem entalhe}

O ensaio de resistência ao impacto Charpy com e sem entalhe foi executado em aparelho de impacto da marca Emic com escala de 0,02 J e faixa de operação de 0,02 a $7,00 \mathrm{~J}$.

Os corpos-de-prova irradiados e não irradiados foram injetados de acordo com a norma ISO 179 e os ensaios foram realizados em estado de injeção como nos testes de tração a $23^{\circ} \mathrm{C}$. Os resultados foram expressos pela média aritmética de cinco determinações. 


\subsubsection{Resistência à flexão e módulo de flexão}

Os ensaios de resistência à flexão e módulo de flexão foram executados na máquina universal de ensaios marca Instron. Os corpos-de-prova irradiados e não irradiados para ambos os ensaios foram injetados de acordo com a norma ISO $178 \mathrm{e}$ foram realizados em estado de injeção como nos testes de tração. Os ensaios foram realizados a $23^{\circ} \mathrm{C}$ em pelo menos três corpos-de-prova por ensaio e os resultados foram obtidos diretamente pelo software do equipamento.

\subsubsection{Resistência ao impacto por queda de dardo}

Esse ensaio foi adaptado da norma ASTM D 5628 pelo laboratório da Radici Plastics e o departamento de engenharia da Bosch Ferramentas. O equipamento é composto de uma haste tubular com escala métrica de $100 \mathrm{~cm}$, presa a um suporte com uma base para colocação do corpo-de-prova. O dardo tem massa de $1 \mathrm{~kg}$ com ponta esférica.

Os ensaios com corpos-de-prova irradiados e não irradiados seguiram os seguintes procedimentos:

a) Posicionar o corpo-de-prova (plaqueta padrão de cor com espessura de $1 \mathrm{~mm}$ ) na base, sob o dardo;

b) apoiar o dardo sobre o corpo-de-prova;

c) elevar o cilindro móvel até uma altura mínima conhecida e soltar;

d) verificar se o corpo-de-prova sofreu deformação significativa ou ruptura. Caso isso tenha ocorrido, realizar mais 3 ensaios na mesma altura e registrar o resultado;

e) caso não ocorra deformação ou ruptura, continuar elevando a altura da queda, até que haja a ocorrência e repetir o ensaio por 3 vezes quando isto ocorrer;

f) registrar os resultados.

O resultado do ensaio foi dado pela altura onde ocorreu a deformação ou ruptura do corpo-de-prova. 
Na Figura 9 é mostrado o equipamento de resistência ao impacto por queda de dardo.

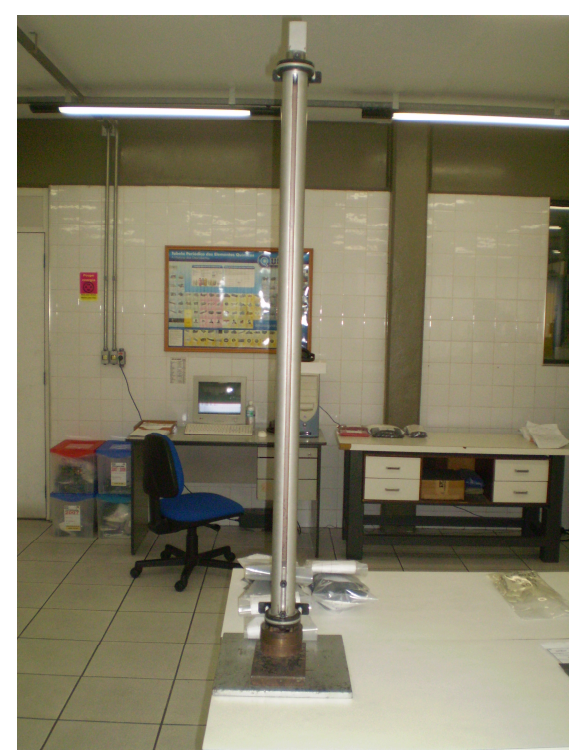

FIGURA 9 - Equipamento de resistência ao impacto por queda de dardo

\subsubsection{Análise de teor de carga}

Neste trabalho utilizou-se para a calcinação do polímero a mufla de microondas à $800^{\circ} \mathrm{C}$ por 10 minutos seguindo os procedimentos exigidos na norma ISO $3451 / 4$ para a execução do ensaio em corpos-de-prova irradiados e não irradiados.

\subsubsection{Densidade}

Os ensaios foram realizados em corpos-de-prova irradiados e não irradiados realizados a $23^{\circ} \mathrm{C}$ e os resultados expressos pela média aritmética de três determinações de acordo com a norma ISO 1183. 


\subsubsection{Resistência ao fio incandescente}

O ensaio de resistência ao fio incandescente foi realizado em equipamento fabricado pela própria Radici Plastics seguindo as especificações regidas pela norma NBR 6272 em corpos-de-prova irradiados e não irradiados.

Uma amostra é considerada como tendo satisfeito ao ensaio do fio incandescente, se ${ }^{[57]}$ :

1) não aparecer qualquer chama visível ou alguma incandescência prolongada no corpo-de-prova;

2) as chamas e a incandescência sobre a amostra se extinguirem dentro dos $30 \mathrm{~s}$ que se seguem a retirada do fio incandescente;

3) caso haja gotejamento na incandescência da amostra, o papel colocado abaixo do corpo-de-prova não deve se inflamar, nem deve ficar chamuscado.

\subsubsection{Calorimetria exploratória diferencial (DSC)}

Foram determinadas as temperaturas de fusão por esta técnica em corposde-prova irradiados e não irradiados em equipamento Mettler Toledo modelo SP 90.

\subsubsection{Temperatura de amolecimento Vicat}

Seguiram-se os procedimentos exigidos na norma ISO 306 para a execução dos ensaios em corpos-de-prova irradiados e não irradiados em equipamento Ceast modelo 6510 .

\subsubsection{Teste de aderência por corte em grade e resistência ao impacto de pedras em superfícies pintadas}

Como muitas peças injetadas com carga mineral tem a pintura como acabamento, este item também foi avaliado neste trabalho por meio de dois processos que medem a aderência da película da tinta sobre o substrato plástico. 
O primeiro teste de aderência da tinta também chamado na indústria de cross-cut test, consiste em efetuar com estilete 10 cortes em grade as superfície da tinta atingindo o substrato, com $1 \mathrm{~mm}$ de lado na grade colando uma fita adesiva tipo Tesa AG 4657 sobre a superfície quadriculada e puxar. Comparar com o padrão para aprovação. O desejado é que não desprenda tinta na fita Gro.

$\mathrm{Na}$ Tabela 6 são apresentados os diferentes graus de avaliação para o teste de aderência por corte em grade ${ }^{[62]}$.

\section{TABELA 6 - Classificação por aparência da superfície cortada em grade após teste de aderência com fita adesiva}

\begin{tabular}{|c|c|c|}
\hline Classificação & Descrição & $\begin{array}{l}\text { Aparência após } \\
\text { teste de aderência }\end{array}$ \\
\hline Gro & $\begin{array}{l}\text { O corte é completamente regular, sem nenhum } \\
\text { desprendimento de tinta }\end{array}$ & \\
\hline Gr1 & $\begin{array}{c}\text { Desplacamento de pequenos flocos de tinta na } \\
\text { intersecção dos cortes. A área desplacada não pode ser } \\
\text { maior que } 5 \%\end{array}$ & $\frac{+1+1}{ \pm+1+1}$ \\
\hline Gr2 & $\begin{array}{l}\text { Desplacamento de tinta no quadrado ou na intersecção } \\
\text { dos cortes. A área desplacada é maior que } 5 \% \text { e menor } \\
\text { que } 15 \%\end{array}$ & $\begin{array}{ll}704 \\
+1+4\end{array}$ \\
\hline Gr3 & $\begin{array}{l}\text { Desplacamento de tinta no quadrado, na intersecção ou } \\
\text { ao longo dos cortes em diferentes áreas. A área } \\
\text { desplacada é maior que } 15 \% \text { e menor que } 35 \%\end{array}$ & मftat \\
\hline Gr4 & $\begin{array}{l}\text { Desplacamento de tinta em alguns quadrados, na } \\
\text { intersecção ou ao longo dos cortes em diferentes áreas. } \\
\text { A área desplacada é maior que } 35 \% \text { e menor que } 65 \%\end{array}$ & \\
\hline Gr5 & Qualquer grau que não pode ser classificado como Gr4 & $-x-$ \\
\hline
\end{tabular}

O segundo teste de aderência é a resistência ao impacto de pedras também conhecido por batida de pedras consiste num jato de pedras com grãos que são peneirados com abertura de malha de $4 \mathrm{~mm}$ e $8 \mathrm{~mm}$ subseqüentes variando o tamanho das pedras de 4 a $8 \mathrm{~mm}$ totalizando $300 \mathrm{~g}$ destas pedras e pressão de jato de 0,8 bar. Este jato com os $300 \mathrm{~g}$ destas pedras, deve escoar por $10 \mathrm{~s}$ após o que a superfície da peça pintada deve ser comparada com o padrão para aprovação ${ }^{[63]}$. 
Na Figura 10 é mostrado o diagrama de uma máquina para efetuar o ensaio de batida de pedra.

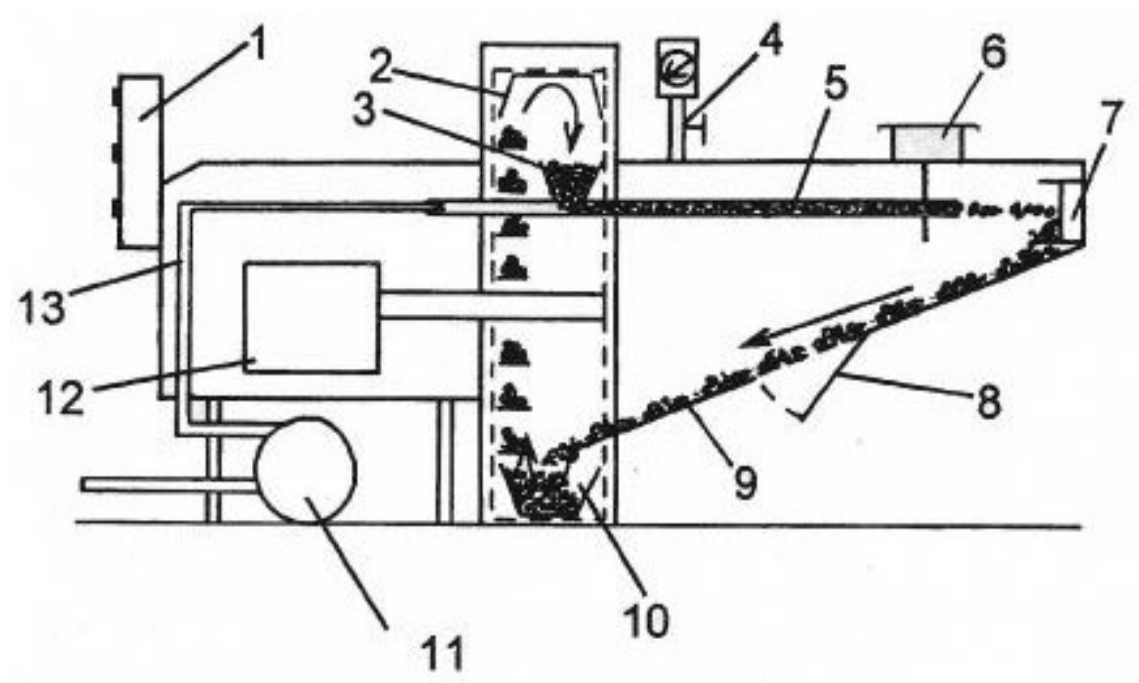

01. Painel de controle

02. Elevador de canecas

03. Funil

04. Válvula de regulagem com manômetro

05. Tubo do bombardeio

06. Abertura de abastecimento

07. Dispositivo de controle
08. Tampa de esvaziamento

09. Plano inclinado

10. Reservatório de areia

11. Reservatório de ar comprimido

12. Motor

13. Tubo de ar comprimido

FIGURA 10 - Esquema de equipamento de batida de pedra

Nas sequências de (a) até (f) da Figura 11 são mostrados os padrões de aparência característicos para aprovação de superfícies pintadas onde foi aplicado o ensaio de resistência ao impacto de pedras. Para aprovação de uma peça de aparência na carroceria de um automóvel e submetida a esse ensaio é desejável que a aparência da superfície pintada esteja classificada de acordo com o padrão de aparência (a). 


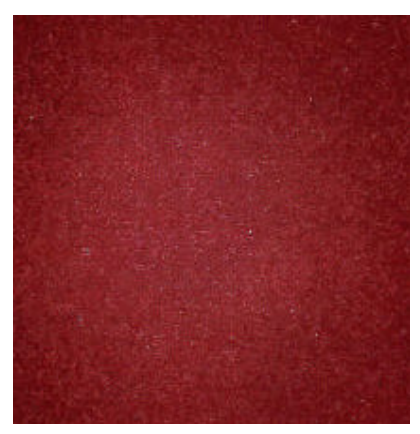

(a)

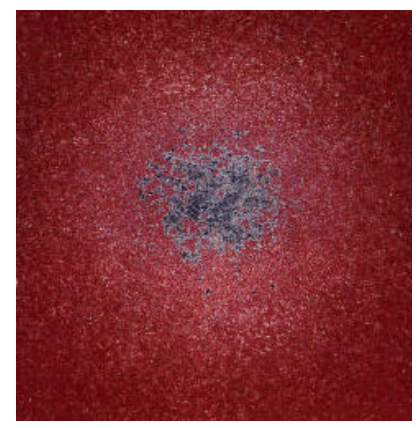

(e)

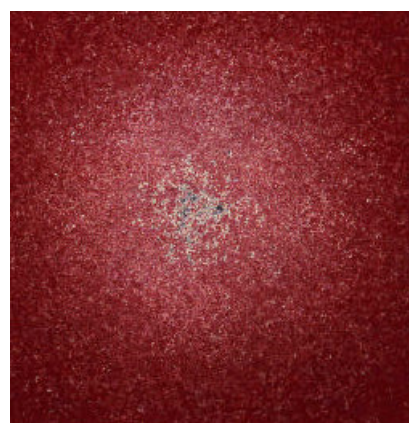

(b)

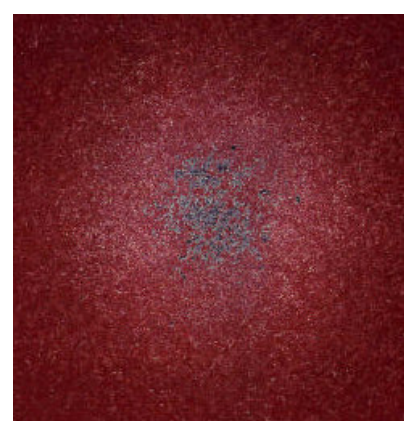

(c)

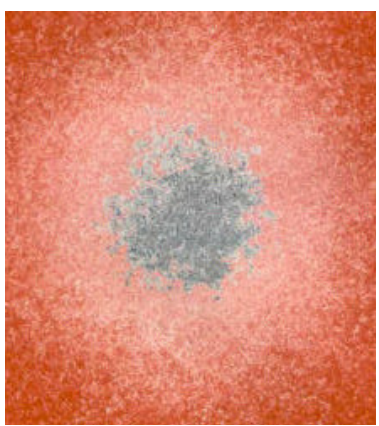

(f)

FIGURA 11 - Padrão de aparência de resistência ao impacto de pedras da superfície mais resistente (a) para a menos resistente (f)

\subsection{Caracterização da CCA}

\subsubsection{Espectrometria de fluorescência de Raios X (FRX)}

A CCA utilizada nesta pesquisa foi submetida a espectrometria de fluorescência de raios $X$ para identificar os compostos constituintes dessa cinza. 


\section{RESULTADOS E DISCUSSÃO}

\subsection{Caracterização química da CCA}

$\mathrm{Na}$ Tabela 7 são apresentados os resultados obtidos pela técnica da espectrometria de fluorescência de raios $X$ realizada nos laboratórios da Votorantin Cimentos em Curitiba, PR, Brasil, em amostra de CCA, cujos laudos são apresentados no Anexo B. Nele é apresentada a composição média dos óxidos em porcentagem de massa da CCA. Os resultados obtidos mostraram a compatibilidade com resultados da literatura.

TABELA 7 - Composição química em porcentagem em massa da CCA MS-325

\begin{tabular}{c|c}
\hline \multicolumn{2}{c}{ AMOSTRA CCA MS-325 } \\
\hline Compostos & \% massa \\
\hline $\mathrm{SiO}_{2}$ & 91,89 \\
\hline $\mathrm{Al}_{2} \mathrm{O}_{3}$ & 0,08 \\
\hline $\mathrm{Fe}_{2} \mathrm{O}_{3}$ & 0,06 \\
\hline $\mathrm{CaO}$ & 0,52 \\
\hline $\mathrm{MgO}$ & 0,33 \\
\hline $\mathrm{K}_{2} \mathrm{O}$ & 1,50 \\
\hline $\mathrm{P}_{2} \mathrm{O}_{5}$ & 0,25 \\
\hline $\mathrm{SO}_{3}$ & 0,06 \\
\hline $\mathrm{TiO}_{2}$ & 0,00 \\
\hline $\mathrm{MnO}$ & 0,25 \\
\hline $\mathrm{Cl}$ & 0,01 \\
\hline $\mathrm{Rb}_{2} \mathrm{O}$ & 0,01 \\
\hline $\mathrm{Co}_{3} \mathrm{O}_{4}$ & 0,05 \\
\hline${ }^{*} \mathrm{PF}$ & 4,80 \\
\hline $\mathrm{Outros}$ & 0,19 \\
\hline TOTAL & $\mathbf{1 0 0 , 0 0}$ \\
\hline TOF - perda ao fogo
\end{tabular}


$\mathrm{Na}$ Tabela 8 são apresentadas as composições químicas do talco e da CCA retirados da literatura ${ }^{[26,28]}$ e a composição da CCA MS-325 utilizada na compostagem da PA 6 nesta pesquisa.

TABELA 8 - Composição química em porcentagem em massa do talco e da CCA obtidos em literatura e a composição da CCA MS-325

\begin{tabular}{cccc}
\hline \multicolumn{4}{c}{ Composição Química (\% em massa) } \\
\hline Compostos & Talco & CCA (literatura) & CCA (MS-325) \\
\hline $\mathrm{SiO}_{2}$ & 58,0 & 89,70 & 91,89 \\
$\mathrm{Fe}_{2} \mathrm{O}_{3}$ & 0,9 & 0,50 & 0,06 \\
$\mathrm{CaO}$ & 0,4 & 1,10 & 0,52 \\
$\mathrm{MgO}$ & 31,0 & 2,00 & 0,33 \\
$\mathrm{~K}_{2} \mathrm{O}$ & 0,02 & 1,50 & 1,50 \\
$\mathrm{Na}_{2} \mathrm{O}$ & 0,04 & 1,60 & - \\
$\mathrm{P}_{2} \mathrm{O}_{5}$ & - & 1,90 & 0,25 \\
$\mathrm{~S}$ & - & 0,90 & 0,06 \\
$\mathrm{Al}_{2} \mathrm{O}_{3}$ & 4,2 & - & 0,09 \\
$\mathrm{TiO}_{2}$ & 0,1 & - & - \\
${ }^{*} \mathrm{PF}$ & 5,4 & 5,00 & 4,80 \\
\hline
\end{tabular}

${ }^{*} \mathrm{PF}$ - perda ao fogo

Os óxidos obtidos no ensaio de fluorescência de Raios $X$ da Microsílica MS 325 são compatíveis com a CCA obtida em literatura. Essa diferença pode ser explicada pela diferença de solo onde o arroz que deu origem a CCA foi cultivado.

Quando comparada ao talco, a diferença significativa está na presença do óxido de magnésio presente em quantidade superior a $30 \%$ no talco.

\subsection{Caracterização da PA $630 \%$ CM (talco e CCA)}

\subsubsection{Ensaios mecânicos}

\subsubsection{Ensaios de resistência mecânica, teor de carga e densidade}

$\mathrm{Na}$ seqüência são apresentados resultados de resistência ao impacto, tração, flexão e os respectivos módulos de elasticidade e flexão. Nesta pesquisa foi 
incluído um teste de impacto por queda livre que foi desenvolvido em conjunto entre os laboratórios da Radici Plastics e o departamento de engenharia da Bosch ferramentas baseado no ensaio de resistência ao impacto por queda de dardo, para simular a quebra da carcaça de uma ferramenta por impacto.

$\mathrm{Na}$ Tabela 9 são apresentados os resultados dos ensaios mecânicos de resistência à tração, alongamento à ruptura, resistência à flexão, módulo de elasticidade, resistência ao impacto Charpy com e sem entalhe, resistência ao impacto por queda de dardo, teor de carga e densidade em corpos-de-prova irradiados e não irradiados.

TABELA 9 - Ensaios de resistência mecânica, teor de carga e densidade da PA $630 \%$ CM (talco) preto e PA $630 \%$ CM (CCA) preto irradiadas e não irradiadas

\begin{tabular}{|c|c|c|c|c|c|}
\hline & $\begin{array}{c}\text { PA } 630 \% \text { CM } \\
\text { (talco) }\end{array}$ & $\begin{array}{c}\text { PA } 630 \% \text { CM } \\
\text { (CCA) }\end{array}$ & $\begin{array}{c}\text { PA } 630 \% \text { CM } \\
\text { (CCA) } \\
\text { 200kGy }\end{array}$ & $\begin{array}{c}\text { PA } 630 \% \mathrm{CM} \\
\text { (CCA) } \\
300 \mathrm{kGy}\end{array}$ & $\begin{array}{c}\text { PA } 630 \% \text { CM } \\
\text { (CCA) } \\
400 \mathrm{kGy}\end{array}$ \\
\hline $\begin{array}{l}\text { Resistência } \\
\text { à tração } \\
\text { (MPa) }\end{array}$ & 63 & 61 & 52 & 52 & 52 \\
\hline $\begin{array}{l}\text { Alongamento à } \\
\text { ruptura } \\
(\%)\end{array}$ & 4 & 4 & 3 & 3 & 3 \\
\hline $\begin{array}{l}\text { Resistência à } \\
\text { flexão } \\
\text { (MPa) }\end{array}$ & 114 & 117 & 99 & 100 & 100 \\
\hline $\begin{array}{l}\text { Módulo de } \\
\text { flexão } \\
\text { (MPa) }\end{array}$ & 5000 & 4531 & 3736 & 3803 & 3860 \\
\hline $\begin{array}{l}\text { Módulo de } \\
\text { elasticidade } \\
\text { (MPa) }\end{array}$ & 4800 & 3332 & 4455 & 4284 & 4154 \\
\hline $\begin{array}{l}\text { Charpy } \\
\text { s/entalhe } \\
\left(\mathrm{kJ} / \mathrm{m}^{2}\right)\end{array}$ & 25 & 21 & 21 & 20 & 22 \\
\hline $\begin{array}{l}\text { Charpy } \\
\text { c/entalhe } \\
\left(\mathrm{kJ} / \mathrm{m}^{2}\right)\end{array}$ & 4 & 4 & 3 & 3 & 4 \\
\hline $\begin{array}{c}\text { ensaio por } \\
\text { queda de dardo } \\
(\mathrm{mm})\end{array}$ & 300 & 1000 & 200 & 200 & 250 \\
\hline $\begin{array}{c}\text { Teor } \\
\text { de carga } \\
(\%)\end{array}$ & 30 & 28 & 27 & 27 & 26 \\
\hline $\begin{array}{l}\text { Densidade } \\
\left(\mathrm{g} / \mathrm{cm}^{3}\right)\end{array}$ & 1,30 & 1,30 & 1,30 & 1,30 & 1,30 \\
\hline
\end{tabular}


Os resultados da Tabela 9 mostraram que o composto de PA 6 com $30 \%$ de CCA teve um desempenho similar ao do composto de PA $630 \%$ talco, porém, o composto com CCA quando submetido ao teste de resistência ao impacto por queda de dardo, teve um desempenho muito superior ao do talco, indicando uma tenacidade muito superior a do talco, essa maior flexibilidade pode ser observada quando analisamos os módulos de flexão e de elasticidade que no composto com CCA são menores. Quanto aos resultados obtidos nos corpos-de-prova irradiados, houve uma pequena diminuição nas propriedades mecânicas indicando que a irradiação provocou um enrijecimento do polímero tornando-o mais frágil.

Na Figura 12 é mostrado o gráfico da tensão em função do alongamento da PA $630 \%$ CM (talco) e da PA $630 \%$ CM (CCA).

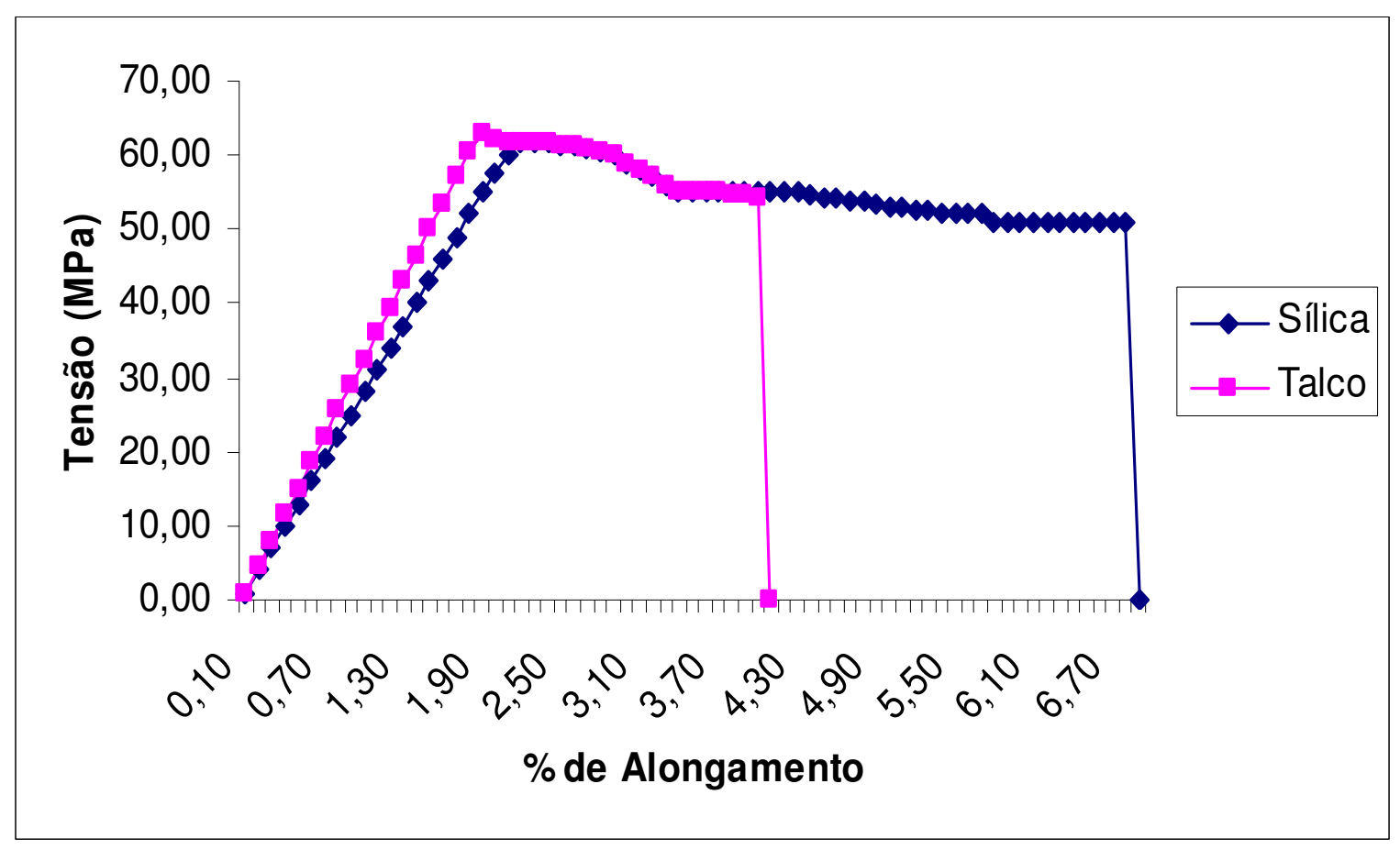

FIGURA 12 - Tensão em função do alongamento da PA $630 \%$ CM (talco e CCA)

De acordo com a Figura 12 a tensão máxima de ruptura da PA $630 \% \mathrm{CM}$ (talco) e da PA $630 \%$ CM (CCA) são próximos porém o alongamento da PA $630 \%$ CM (CCA) é cerca de $35 \%$ maior que o produto composto com talco. 


\subsubsection{Teste de aderência em grade e ensaio de resistência ao impacto de batida de pedras}

Como muitas peças injetadas com carga mineral tem a pintura como acabamento, a aderência da tinta na portinhola de combustível do automóvel modelo Pólo da marca Volkswagen (VW) injetada em PA 6 com 30\% CCA também foi avaliada.

Nesta pesquisa a aderência da tinta no composto injetado foi avaliada por meio do ensaio de aderência por grade e pelo ensaio de resistência ao impacto de batida de pedras (Figura 13) consideradas aprovadas de acordo com os critérios estipulados pelas montadoras.

Na Figura 13 são mostradas fotos (a) e (b) de peças injetadas com PA $630 \%$ CCA pintadas onde efetuou-se o teste de batida de pedras e o de aderência de tinta pelo método de grade.

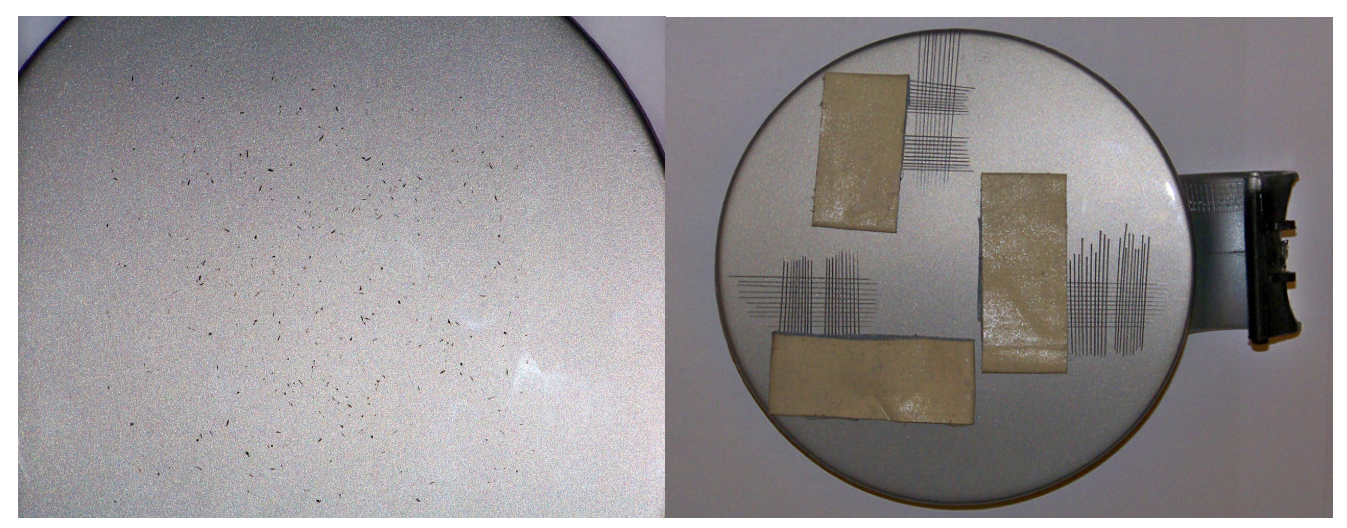

(a)

(b)

FIGURA 13 - Peças submetidas ao ensaio de batida de pedras (a) e de aderência por corte em grade de pintura (b) na portinhola do automóvel Pólo VW

De acordo com o observado na Figura 13 existe uma similaridade com o padrão (1) para o ensaio de batida de pedras e o resultado Gro para o teste de aderência no corte de grade, satisfazendo as exigências de aprovação da montadora para estes testes. 


\subsubsection{Ensaios térmicos}

\subsubsection{Ensaio de fio incandescente}

$\mathrm{Na}$ Tabela 10 são apresentados os resultados do ensaio de fio incandescente que visa simular o calor liberado por uma fonte de energia em um curto circuito elétrico, como tomadas, disjuntores e outros.

TABELA 10 - Ensaios de fio incandescente, da PA 6 com 30\% CM (talco) e PA 6 30\% CCA em amostras irradiadas e não irradiadas

\begin{tabular}{|c|c|c|c|}
\hline \multirow{2}{*}{ Composto } & \multicolumn{3}{|c|}{ Fio incandescente } \\
\hline & $750^{\circ} \mathrm{C}$ & $850^{\circ} \mathrm{C}$ & $960^{\circ} \mathrm{C}$ \\
\hline PA $630 \%$ CM & $\mathrm{R}$ & NR & NR \\
\hline PA $630 \%$ CCA & $\mathrm{R}$ & NR & NR \\
\hline PA 6 30\% CCA (200 kGy) & $\mathrm{R}$ & NR & NR \\
\hline PA 6 30\% CCA (300 kGy) & NR & NR & NR \\
\hline PA 6 30\% CCA (400 kGy) & NR & NR & NR \\
\hline
\end{tabular}

R: resiste, NR: não resiste

Com base nos valores apresentados na Tabela 10 indica-se a similaridade do composto de PA 6 com talco e com CCA no ensaio de fio incandescente resistindo a temperatura de $750^{\circ} \mathrm{C}$. Quanto a PA 6 com 30\% CCA irradiada a 200 kGy teve comportamento similar às não irradiadas. As irradiadas com 300 e 400 kGy não passaram no ensaio.

\subsubsection{Temperatura de amolecimento Vicat}

$\mathrm{Na}$ Tabela 11 são apresentados os resultados do ensaio de amolecimento Vicat. 
TABELA 11 - Ensaio de amolecimento Vicat da PA $630 \%$ carga mineral (CM) e PA $630 \%$ cinza de casca de arroz (CCA) em amostras irradiadas e não irradiadas

\begin{tabular}{lc}
\hline \multicolumn{1}{c}{ Composto } & Vicat (ㄷ) \\
\hline PA 6 30\% CM & 210 \\
PA 6 30\% CCA & 220 \\
PA 6 30\% CCA (200 kGy) & 210 \\
PA 6 30\% CCA (300 kGy) & 190 \\
PA 6 30\% CCA (400 kGy) & 190 \\
\hline
\end{tabular}

Os resultados apresentados na Tabela 11 indicam temperaturas de amolecimento Vicat compatíveis com compostos de carga mineral ou seja, perto da temperatura de fusão do polímero há um amolecimento do material. Quanto a PA 6 com 30\% CCA irradiada a 200k Gy teve comportamento similar às amostras não irradiadas. As irradiadas com 300 e 400 kGy tiveram desempenho abaixo do estimado para compostos dessa natureza, indicando uma possível degradação da estrutura do polímero.

\subsubsection{Temperatura de fusão (DSC)}

$\mathrm{Na}$ Tabela 12 são apresentadas as temperaturas de fusão pela técnica de DSC da PA 6 30\% CM e PA 6 30\% CCA irradiadas e não irradiadas. 
TABELA 12 - Temperatura de fusão da PA $630 \%$ CM e 30\% CCA irradiadas e não irradiadas

\begin{tabular}{lc}
\hline \multicolumn{1}{c}{ Composto } & Temperatura de Fusão (ㄷ) \\
\hline PA 6 30\% CM & 220 \\
PA 6 30\% CCA & 220 \\
PA 6 30\% CCA (200 kGy) & 220 \\
PA 6 30\% CCA (300 kGy) & 220 \\
PA 6 30\% CCA (400 kGy) & 220 \\
\hline
\end{tabular}

De acordo com os resultados da Tabela 12, verificou-se que não houve alteração nas temperaturas de fusão mantendo-se dentro do esperado para uma PA 6 para os corpos-de-prova irradiados e não irradiados.

\subsection{Moldagem por injeção (processamento)}

A injeção de peças para avaliar o processamento do composto de PA $630 \%$ CCA preto foi realizada na linha de produção da CGE Sociedade Fabricadora de Peças Plásticas Ltda. e na Tyco Electronics Brasil Ltda..

Foi acompanhada a injeção da capa de correia do automóvel Celta da General Motors (GM), onde o material especificado é PA $630 \% \mathrm{CM}$ preta e substituímos pela PA $630 \%$ CM (CCA) preta injetada em máquina injetora Haitian HTF $300 X$ de 300 toneladas de fechamento.

Do ponto de vista de processamento esta peça possui algumas dificuldades de injeção, como por exemplo, preenchimento do molde devido o tamanho e geometria dessa peça tendo que trabalhar com pressão de recalque, inclusão de insertos metálicos, acabamento sem manchas de fluxo na superfície da peça devido a cor branca das cargas minerais convencionais.

$\mathrm{Na}$ Tabela 13 são apresentados os parâmetros de injeção do produto formulado com talco e o mesmo produto formulado com CCA. 
TABELA 13 - Parâmetros de injeção para a capa de correia GM ePA 6 30\% CM

\begin{tabular}{lcc}
\hline \multicolumn{3}{c}{ Parâmetros de Injeção PA 6 30\% CM preto } \\
\hline Indicadores & Formulado com Talco & Formulado com CCA \\
\hline Pressão de Injeção & $110 \mathrm{bar}$ & $100 \mathrm{bar}$ \\
Velocidade de injeção & $70 \mathrm{~cm}^{3} / \mathrm{s}$ & $63 \mathrm{~cm}^{3} / \mathrm{s}$ \\
Tempo de injeção & $3,5 \mathrm{~s}$ & $3,5 \mathrm{~s}$ \\
Curso de dosagem & $257 \mathrm{~mm}$ & $257 \mathrm{~mm}$ \\
Pressão de recalque & $25 \mathrm{bar}$ & $25 \mathrm{bar}$ \\
Velocidade de recalque & $17 \mathrm{~cm}^{3} / \mathrm{s}$ & $17 \mathrm{~cm}^{3} / \mathrm{s}$ \\
Tempo de recalque & $0,5 \mathrm{~s}$ & $0,5 \mathrm{~s}$ \\
$*$ Temperatura ${ }^{\circ} \mathrm{C}:$ Z1, Z2, Z3, Z4 & $310,305,295,290$ & $295,290,285,280$ \\
Ciclo total de injeção & $50 \mathrm{~s}$ & $50 \mathrm{~s}$ \\
\hline
\end{tabular}

${ }^{*}$ Z1, Z2, Z3 e Z4 correspondem às temperaturas na zona de alimentação (Z1), transição $(Z 2, Z 3)$ e homogeneização $(Z 4)$ do material na unidade de plastificação (rosca) da injetora.

Na Figura 14 é mostrado o esquema de uma rosca universal usada na unidade de plastificação de uma máquina injetora de plásticos.

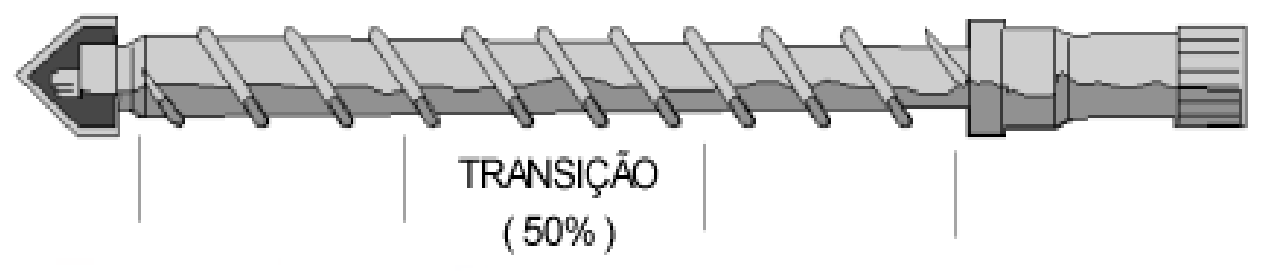

HOMOGENEIZAÇÄ̃O

$(25 \%)$
ALIMENTAÇÃO

$(25 \%)$

FIGURA 14 - Representação de uma rosca universal da unidade de plastificação de uma máquina injetora de plásticos

Ao analisar-se os dados dos parâmetros de injeção com os dois tipos de material (formulado com talco e formulado com CCA) apresentados na Tabela 13 pode-se admitir que o material formulado com CCA tem melhor fluidez que o produto formulado com talco devido as temperaturas de injeção nas 4 zonas de plastificação 
da rosca e a pressão de injeção serem mais baixas para o produto formulado com CCA.

Na Figura 15 é mostrada a capa de correia GM injetada com PA $630 \%$ CM (CCA) preto mostrando a parte interna com insertos metálicos e a parte externa.

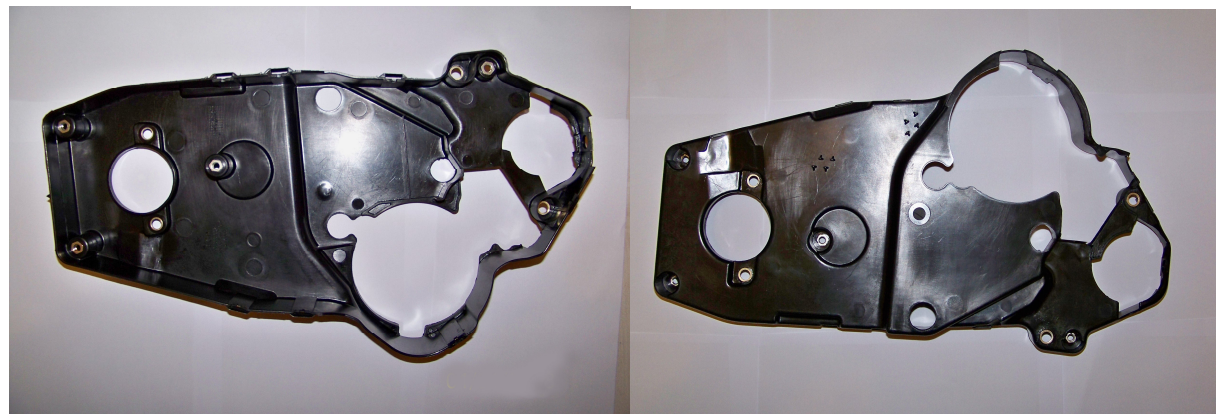

FIGURA 15 - Capa de correia GM injetada com PA 6 30\% CCA preto em injetora Haitian de 350 t de fechamento e molde com 1 cavidade

Outro problema na injeção da capa da correia mostrada na Figura 15 são as marcas de fluxo causadas pela carga mineral que normalmente é branca, problema este não encontrado com o produto formulado com a CCA porque é naturalmente preta não realçando as marcas, aumentando inclusive, a resistência ao risco. A capa de correia injetada com a CCA teve comportamento compatível com a qualidade esperada para a peça.

Na Figura 16 é mostrada a máquina injetora utilizada para a injeção da capa de correia GM com o molde aberto e a peça sendo extraída enquanto o operador introduz os insertos metálicos preparando a máquina para o novo ciclo de injeção.

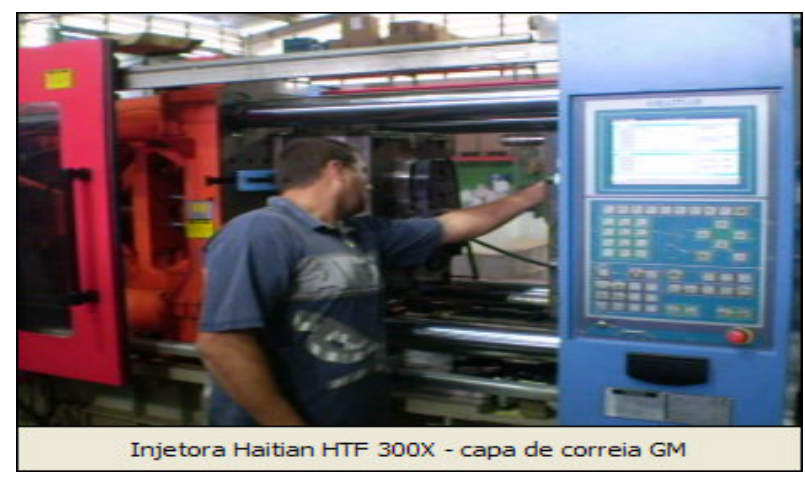

FIGURA 16 - Máquina injetora Haitian utilizada na injeção da capa de correia GM com o molde da tampa de correia aberto 
O ciclo de injeção (tempo total de injeção a partir do fechamento do molde até a extração da peça) da capa de correia injetado com a PA $630 \%$ CCA mantevese igual ao do produto formulado com talco não trazendo prejuízo na produtividade da peça.

$\mathrm{Na}$ Figura 17 é mostrado o esquema de uma máquina injetora de termoplásticos com as unidades de fechamento, de injeção, de controle, sistema hidráulico e o molde ${ }^{[64]}$.

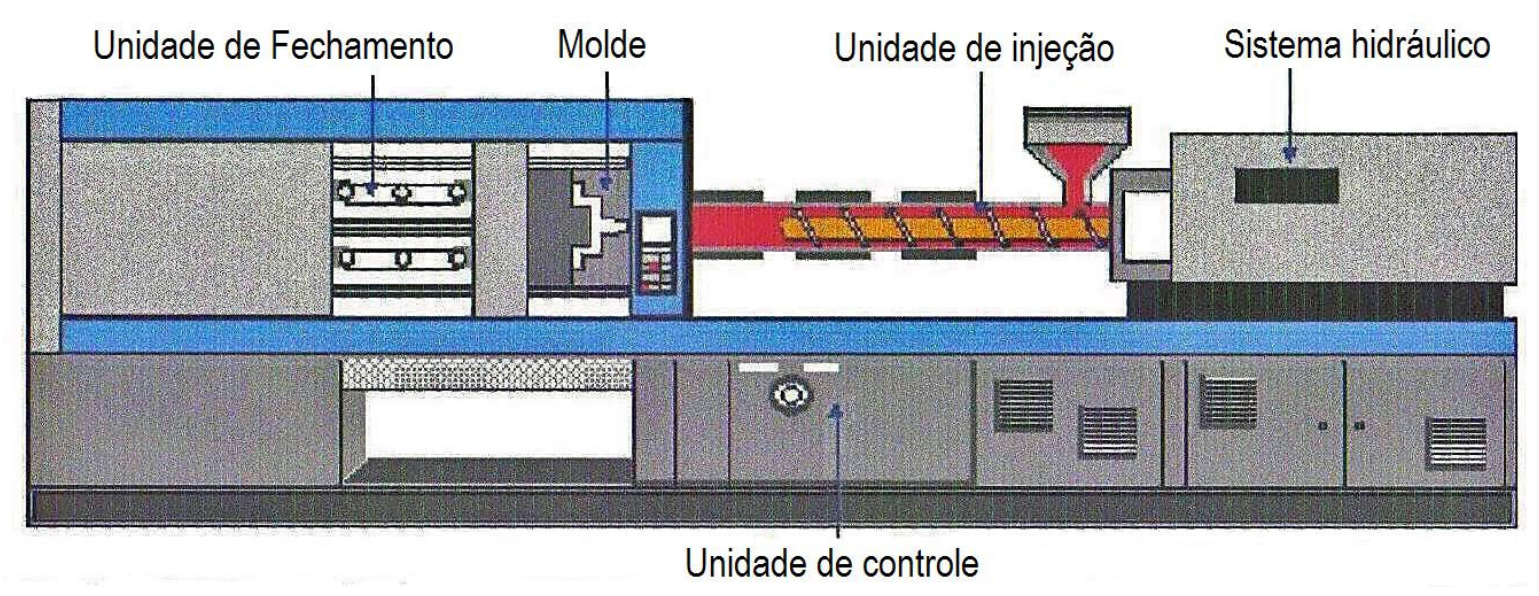

FIGURA 17 - Esquema de uma máquina injetora de termoplásticos

Na Figura 18 é mostrada a foto da potinhola de combustível do automóvel Pólo da VW injetada com PA $630 \%$ CCA e na Figura 19 a foto da mesma peça pintada de acordo com as especificações da montadora (fundo poliuretano - PU, base prata e verniz).

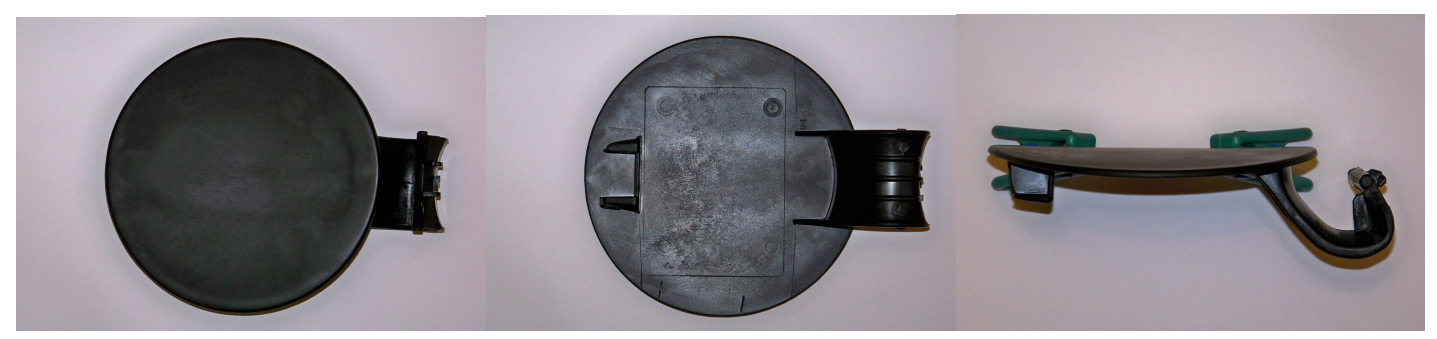

FIGURA 18 - Portinhola da tampa do combustível do automóvel Pólo VW injetado com PA $630 \%$ CCA preto em injetora Romi de 300t de fechamento e molde com 2 cavidades 


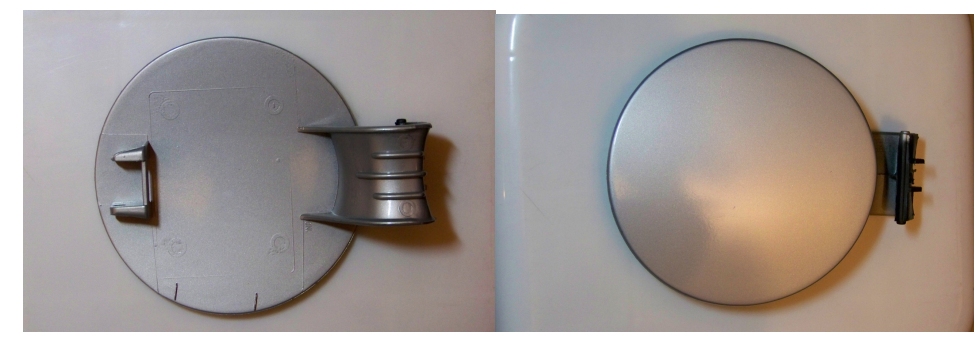

FIGURA 19 - Portinhola da tampa de combustível do automóvel Pólo VW pintada com fundo PU, base prata e acabamento em verniz acrílico catalisado

Nas Figuras 18 e 19 são mostradas as fotos da portinhola do automóvel Pólo da VW injetadas com a PA $630 \%$ CCA. As peças injetadas com esse material passaram por dispositivo de medida que refuga imediatamente as peças injetadas que não atinjam as dimensões previstas neste gabarito evitando que peças com dimensional prejudicado não cheguem a serem pintadas.

As peças injetadas com PA $630 \%$ CCA se comportaram da forma prevista pelo especificado para este produto. Outro ponto importante é que as peças injetadas com esse material não apresentaram chupagem (depressão) na área de confluência da haste de fixação com a tampa da portinhola que é ressaltada após a pintura.

Na Figura 20 é mostrado um conector de cabos do automóvel Fox da VW, injetada com PA $630 \%$ CCA.
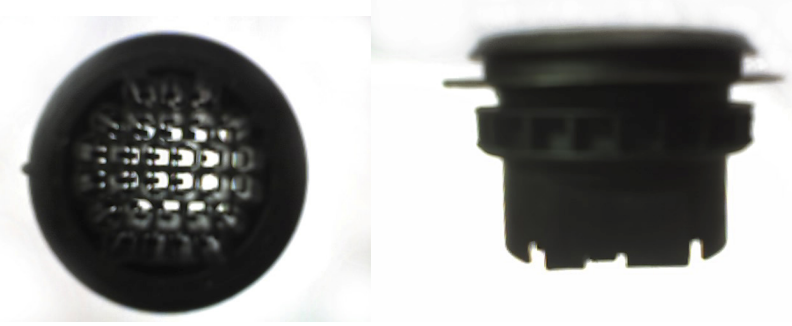

FIGURA 20 - Conector VW Fox injetado com PA 6 30\% CCA preto em injetora Engle de $200 \mathrm{t}$ de fechamento e molde de 2 cavidades 
O ponto crítico na injeção da peça mostrada na Figura 20 é o perfeito preenchimento da colméia central do conector onde serão passados e fixados os cabos e terminais de contato, dificuldade esta plenamente contornada com o material formulado com CCA devido a sua boa fluidez.

De um modo geral, o processamento da PA 6 com 30\% CCA não altera significativamente os parâmetros de injeção de um produto formulado com talco mantendo os mesmos ciclos de injeção, indicando que a CCA não interfere no tempo de cristalização da poliamida 6 .

Observou-se uma melhor fluidez do produto formulado com CCA permitindo a injeção de peças com geometria mais complexa. Manteve a contração das peças injetadas com PA $630 \%$ CCA em níveis desejados para produtos desta natureza $(0,7 \%)$. Nas peças em que testou-se esse material, não constatou-se problemas de chupagem, acabamento superior por não apresentar marcas de fluxo recorrentes de um produto formulado com talco e melhor resistência ao risco pelo fato da carga (CCA) ser preta e não acentuar as marcas.

\subsection{Viabilidade econômica}

Na seqüência apresentamos três formulações básicas de compostos de PA 6 $30 \%$ carga mineral para comparação de custos, sendo que em duas das formulações utilizou-se como carga o talco e em outra a CCA.

Como o composto de PA 6 com CCA apresenta resistência ao impacto superior após hidratação espontânea, em uma das duas formulações feitas com talco foi acrescentado um modificador de impacto (MI) que confere a PA 6 formulada com talco as mesmas propriedades de resistência de uma PA 6 formulada com CCA sem MI.

Nas Tabelas 13, 14 e 15 são apresentados os custos para formulação da PA 6 30\% CM (talco) preto, PA 6 30\% CM (CCA) preto e PA $630 \%$ CM (talco) preto mais $4 \%$ de modificador de impacto $(\mathrm{MI})$, respectivamente. 
TABELA 13 - Custo total/kg para a fórmula de PA $630 \%$ CM (talco) preto

\begin{tabular}{lccc}
\hline Descrição MP & $\begin{array}{c}\text { Participação } \\
(\%)\end{array}$ & $\begin{array}{c}\text { Custo Unit. } \\
(\mathbf{R} \$)\end{array}$ & $\begin{array}{c}\text { Custo da } \\
\text { Dose (R\$) }\end{array}$ \\
\hline CARGA MINERAL TIPO I (TALCO) & $30,00 \%$ & 0,61 & 0,18 \\
MB PRETO PE 40\% & $3,00 \%$ & 6,01 & 0,18 \\
ACETATO DE COBRE & $0,02 \%$ & 42,05 & 0,01 \\
IODETO DE POTASSIO & $0,01 \%$ & 110,25 & 0,01 \\
OLEO SILICONE 200/1000 & $0,10 \%$ & 9,36 & 0,01 \\
LUBRIFICANTE II & $0,30 \%$ & 3,69 & 0,01 \\
PA 6 NATURAL (VISCOSIDADE 3,8) & $15,00 \%$ & 5,40 & 0,81 \\
PA 6 NATURAL STANDARD & $51,57 \%$ & 5,45 & 2,81 \\
\hline \multicolumn{3}{c}{ CUSTO TOTAL/kg SEM IMPOSTOS } \\
\hline
\end{tabular}

TABELA 14 - Custo total/kg para a fórmula de PA $630 \%$ CM (CCA) preto

\begin{tabular}{lccc}
\hline \multicolumn{1}{c}{ Descrição MP } & $\begin{array}{c}\text { Participação } \\
\%\end{array}$ & $\begin{array}{c}\text { Custo Unit. } \\
(\mathbf{R} \$)\end{array}$ & $\begin{array}{c}\text { Custo da } \\
\text { Dose (R\$) }\end{array}$ \\
\hline CARGA MINERAL TIPO I (CCA) & $30,00 \%$ & 0,75 & 0,23 \\
MB PRETO PE 40\% & $0,00 \%$ & 6,01 & 0,0 \\
ACETATO DE COBRE & $0,02 \%$ & 42,05 & 0,01 \\
IODETO DE POTASSIO & $0,01 \%$ & 110,25 & 0,01 \\
OLEO SILICONE 200/1000 & $0,10 \%$ & 9,36 & 0,01 \\
LUBRIFICANTE II & $0,30 \%$ & 3,69 & 0,01 \\
PA 6 NATURAL (VISCOSIDADE 3,8) & $15,00 \%$ & 5,40 & 0,81 \\
PA 6 NATURAL STANDARD & $54,57 \%$ & 5,45 & 2,97 \\
\hline \multicolumn{2}{c}{ CUSTO TOTAL/kg SEM IMPOSTOS } \\
\hline
\end{tabular}

TABELA 15 - Custo total/kg para a fórmula de PA $630 \%$ CM (talco) MI preto

\begin{tabular}{lccc}
\hline \multicolumn{1}{c}{ Descrição MP } & $\begin{array}{c}\text { Participação } \\
\%\end{array}$ & $\begin{array}{c}\text { Custo Unit. } \\
\text { (R\$) }\end{array}$ & $\begin{array}{c}\text { Custo da } \\
\text { Dose (R\$) }\end{array}$ \\
\hline CARGA MINERAL TIPO I (TALCO) & $30,00 \%$ & 0,61 & 0,18 \\
MB PRETO PE 40\% & $3,00 \%$ & 6,01 & 0,18 \\
ACETATO DE COBRE & $0,02 \%$ & 42,05 & 0,01 \\
IODETO DE POTASSIO & $0,01 \%$ & 110,25 & 0,01 \\
OLEO SILICONE 200/1000 & $0,10 \%$ & 9,36 & 0,01 \\
LUBRIFICANTE II & $0,30 \%$ & 3,69 & 0,01 \\
PA 6 NATURAL (VISCOSIDADE 3,8) & $15,00 \%$ & 5,40 & 0,81 \\
PA 6 NATURAL STANDARD & $47,57 \%$ & 5,45 & 2,59 \\
MODIFICADOR DE IMPACTO I & $4,00 \%$ & 8,77 & 0,35 \\
\hline \multicolumn{2}{c}{ CUSTO TOTAL/kg SEM IMPOSTOS } \\
\hline
\end{tabular}


O custo da formulação com a CCA é praticamente igual ao do mesmo produto formulado com talco ou seja, 0,01\% mais caro. Porém quando é inserido o modificador de impacto na formulação com talco para dar a mesma tenacidade que 0 produto formulado com a CCA, a diferença é significativa, ou seja, 2,5\% mais caro que o produto formulado com a CCA.

É preciso levar em conta também, que o custo da CCA ainda é alto porque as aplicações para esta carga ainda são limitadas, porém com as novas pesquisas para novas aplicações pode-se aumentar significativamente o consumo da CCA e seu custo deverá cair significativamente deixando os compostos formulados com CCA ainda mais competitivos.

Neste levantamento de custos não foi levado em consideração o alto custo ambiental proveniente da obtenção do talco das jazidas naturais e o ganho enorme no fechamento de um ciclo virtuoso na produção do arroz a partir do seu beneficiamento, da geração de energia pela queima da casca e a utilização da cinza gerada em polímeros agregando valor a este resíduo. 


\section{CONCLUSÕES}

A CCA mostrou-se uma alternativa viável para a substituição do talco como uma carga para a PA 6 por apresentar resistências mecânicas e térmicas semelhantes com as de um composto de PA 6 formulado com talco. No ensaio de fio incandescente a resistência ao gotejamento foi superior, propriedade importante na formulação de produtos antichama.

A CCA apresentou resultado muito superior ao talco na resistência ao impacto por queda de dardo, comparável a um produto formulado com modificador ao impacto que leva a uma considerável redução de custo.

A coloração da CCA nas concentrações acima de 20\% elimina a necessidade de acrescentar negro de fumo nas formulações para se conseguir um produto na cor preta. Como a CCA confere ao composto uma cor preta, o produto acabado fica isento de manchas causadas pelas marcas de fluxos que são usuais em produtos formulados com o talco que é branco.

Quanto ao processamento, o produto formulado com CCA teve comportamento similar ao produto formulado com talco, não havendo maiores conseqüências aparentes numa possível troca de produto.

A perda ao fogo da CCA na calcinação de corpos-de-prova a $700^{\circ} \mathrm{C}$ para análise de teor de carga do composto é aproximadamente 12\%. Esse fato deve ser explicitado na ficha técnica do produto formulado com CCA porque um produto formulado com 30\% de CCA ao ser calcinado apresenta como resíduo $26,4 \%$ de CCA. Os outros 3,6 perdem-se na calcinação (perda ao fogo).

Com relação ao custo, o produto formulado com CCA ficou praticamente igual ao do produto formulado com talco e mais barato quando comparado com o mesmo produto (talco) mais o modificador de impacto, porém, o ganho ambiental é muito grande porque estamos fechando o ciclo da produção do arroz com o aproveitamento total de seu resíduo, a casca, com uma destinação nobre a sua cinza.

A irradiação da PA 6 30\% CCA não trouxe ganhos mecânicos ou térmicos significativos ao composto. 
Outros ensaios térmicos e ensaios de longa duração ainda se fazem necessários para uma utilização total e segura deste resíduo como uma alternativa para o talco como uma carga para a PA 6. Porém pelos resultados iniciais, as perspectivas são animadoras, mostrando melhoria na qualidade do produto, redução de custos e ganho ambiental. 


\section{SUGESTÕES PARA TRABALHOS FUTUROS}

* Utilização das técnicas MEV ou MIT para estudar a interação da CCA com o polímero, irradiando as amostras a diferentes doses e submetidas à fratura.

* Estudo da resistência da PA 6 com 30\% CCA a diversos solventes após irradiação.

* Estudo da temperatura de deflexão térmica (HDT) da PA 6 com 30\% CCA não irradiadas e irradiadas a diferentes doses.

* Resistência à hidrólise da PA 6 com 30\% CCA não irradiadas e irradiadas a diferentes doses.

* Cálculo de Viscosidade e Resistividade Volumétrica da PA 6 30\% CCA.

* Irradiação dos grãos de PA 6 30\% CCA submetidas a diferentes doses de radiação e verificar o seu desempenho no processamento por injeção e medir as suas propriedades mecânicas, térmicas e reológicas.

* Irradiação da CCA submetida a diferentes doses de radiação e fazer a compostagem com PA 6 em diferentes porcentagens (20, 30 e $40 \%$ ) e medir as suas propriedades mecânicas, térmicas e reológicas.

* Estudo da $T_{g}$ por análise termogravimétrica da PA 6 30\% CCA submetida a diferentes doses de radiação.

- Estudo da percentagem de cristalinidade da PA 6 30\% CCA submetida a diferentes doses de radiação por DSC.

* Determinação da área específica da CCA utilizada nesta pesquisa. 


\section{ANEXO A - Normas utilizadas no trabalho}

\begin{tabular}{|c|c|}
\hline \multicolumn{2}{|r|}{ ISO - International Organization for Standardization } \\
\hline \multicolumn{2}{|r|}{ Plastic test standard } \\
\hline ISO - 1183/1: 2004 & Methods for determining the density of non-cellular plastics \\
\hline ISO - 3451/4: 1998 & Determination of ash - part 4: Polyamides \\
\hline ISO - 179/2: 1997 & Determination of Charpy impact properties - instrumented impact \\
\hline ISO - 527/1: 1993 & Determination of tensile properties \\
\hline ISO - 178: 2001 & Determination of flexural properties \\
\hline ISO - 306: 2004 & Determination of the Vicat softening temperature (VST) \\
\hline ISO - 2409: 2007 & Paints and varnishes - cross cut test \\
\hline ISO 16276-2: 2007 & $\begin{array}{l}\text { Corrosion protection of steel structures by protective paint systems. } \\
\text { Assessment of, and acceptance criteria for, the adhesion/cohesion } \\
\text { (fracture strength) of a coating, Part 2: Cross-cut testing and X-cut } \\
\text { testing }\end{array}$ \\
\hline \multicolumn{2}{|r|}{ DIN - Deutsches Institut für Normung } \\
\hline DIN - 50014 & Climates and their technical application, standard atmospheres \\
\hline & ASTM - International Standard Worldwide \\
\hline ASTM D $5628-07$ & $\begin{array}{l}\text { Standard Test Method for Impact Resistance of Flat, Rigid Plastic } \\
\text { Specimens by Means of a Falling Dart (Tup or Falling Mass) }\end{array}$ \\
\hline
\end{tabular}


ANEXO B - Laudo da caracterização da CCA por fluorescência de Raios X

$V$ Votorantim | Cimentos

Diretoria Técnica - Laboratório de Raios-X CERTIFICADO DE ANÁLISES

Identificação: amostra coletada na empresa Cereais Passo Ltda (CCA)

Data: 28-Apr-06 Solicitante: João Jaime Less

Analista: José Carlos Cordeiro

Tipo de Análise: Espectrometria de fluorescência de raios-X (FRX).

Análise Semi-Quantitativa, não pode ser usada como critério para liberação de coprocessamento de resíduos. (Pastilha)

\begin{tabular}{|l|c|}
\hline \multicolumn{1}{|c|}{ AMOSTRA } & $\begin{array}{c}\text { Cinza de casca } \\
\text { de arroz }\end{array}$ \\
\hline \multicolumn{1}{|c|}{ CÓDO VC } & $\mathbf{1 9 6 7}$ \\
\hline $\mathrm{SiO}_{2}(\%)$ & 91,89 \\
\hline $\mathrm{Al}_{2} \mathrm{O}_{3}(\%)$ & 0,08 \\
\hline $\mathrm{Fe}_{2} \mathrm{O}_{3}(\%)$ & 0,06 \\
\hline $\mathrm{CaO}(\%)$ & 0,52 \\
\hline $\mathrm{MgO}(\%)$ & 0,33 \\
\hline $\mathrm{K}_{2} \mathrm{O}(\%)$ & 1,50 \\
\hline $\mathrm{P}_{2} \mathrm{O}_{5}(\%)$ & 0,25 \\
\hline $\mathrm{SO}_{3}(\%)$ & 0,06 \\
\hline $\mathrm{TiO}_{2}(\%)$ & 0,00 \\
\hline $\mathrm{MnO}(\%)$ & 0,25 \\
\hline $\mathrm{Cl}(\%)$ & 0,01 \\
\hline $\mathrm{Rb}_{2} \mathrm{O}(\%)$ & 0,01 \\
\hline $\mathrm{CO}_{3} \mathrm{O}_{4}(\%)$ & 0,05 \\
\hline${ }^{\circ} \mathrm{PF}(\%)$ & 4,80 \\
\hline $\mathrm{Outros}(\%)$ & 0,19 \\
\hline TOTAL (\%) & $\mathbf{1 0 0 , 0 0}$ \\
\hline
\end{tabular}

*PF - perda ao fogo

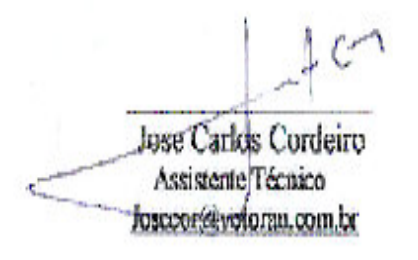




\section{Votorantim | Cimentos}

\section{Laboratório Central}

\subsection{Identificação da Amostra: Cinza de casca de arroz}

Código VC: 1967.06 Operador: Rodrigo Manoel do Nascimento

\subsection{Gráfico:}

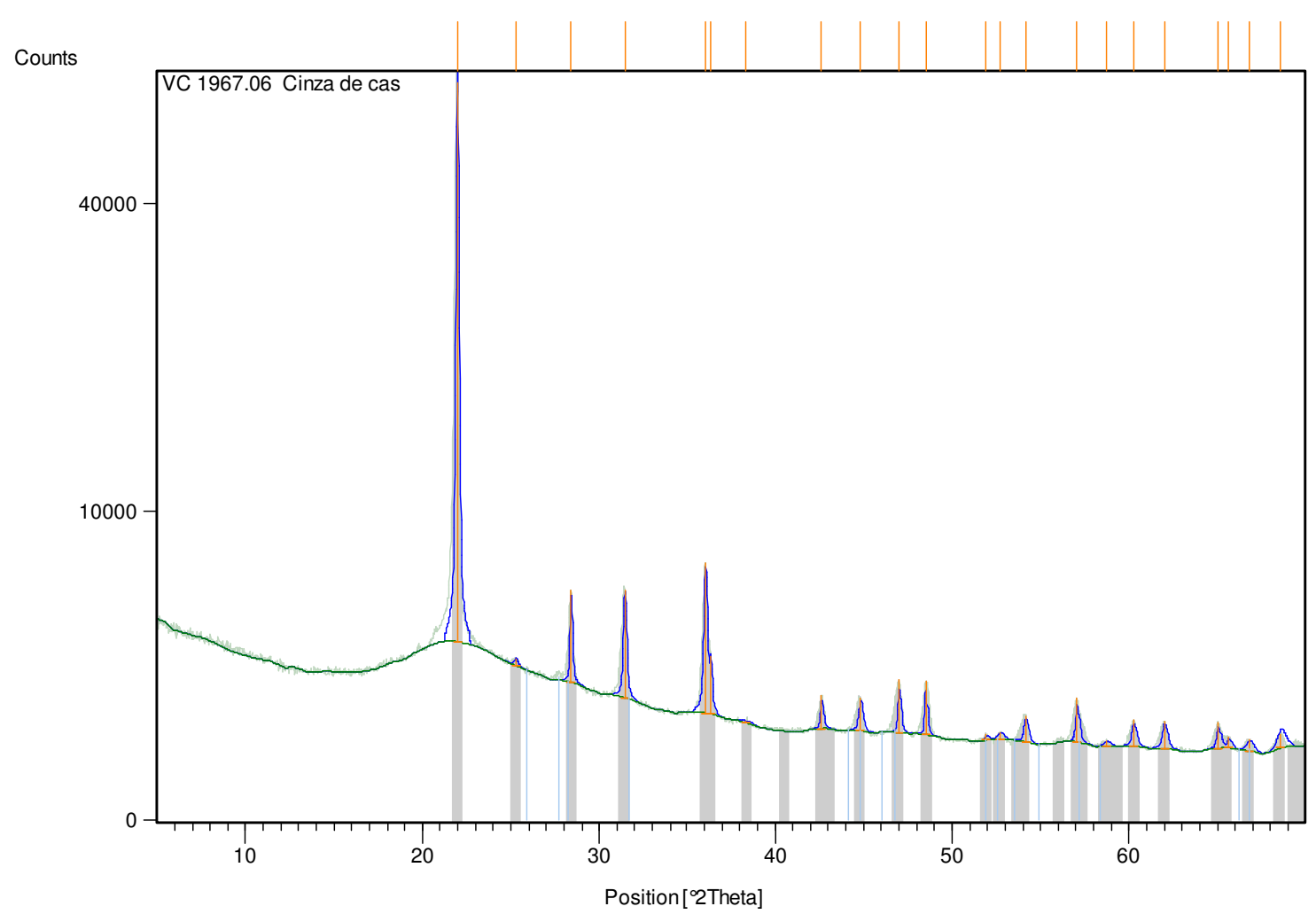

\subsection{Lista de compostos identificados:}

\begin{tabular}{cccccc}
\hline Ref. Code & Score & Compound Name & Scale Factor & Chemical Formula & SemiQuant [\%] \\
\hline $01-071-0785$ & 75 & Cristobalite low & 0,983 & $\mathrm{Si} \mathrm{O}_{2}$ & 100 \\
\hline
\end{tabular}




\section{REFERÊNCIAS BIBLIOGRÁFICAS}

1. IPT, CEMPRE Lixo Municipal, Manual de Gerenciamento Integrado. PÁGINAS \& LETRAS - Editora e Gráfica Ltda., março de 1998.

2. ROSE, R. A gestão empresarial e a questão ambiental. Artigo publicado no site http//www.reciclagem.net, diretor de meio ambiente da câmara BrasilAlemanha acesso em janeiro 2004.

3. PLÁSTICO INDUSTRIAL Dana Amplia Produção de Autopeças em Termoplásticos no Brasil. Aranda Editora Técnica Cultural Ltda., ano II, № 18, fevereiro 2000.

4. BOLT, R.O.; CARROL, J.G. Radiation Effects on Organic Materials. New York, NY. Academic Pr., 1963.

5. CLOUGH, R.L.; SHALABY, S.W. Radiation Effects on Polymers. Washington, D. C., American Chemical Society, 1991.

6. EVORA, M.C. Estudo do Efeito da Radiação sobre a Poliamida-6 Reciclada. 2001, Dissertação (Mestrado) - Instituto de Pesquisas Energéticas e Nucleares, São Paulo.

7. EVORA, M.C.; GONÇALEZ, O.L.; WIEBECK, H.; MACHADO, L.D.B.; ANDRADE E SILVA, L.G. Análise dos efeitos da radiação ionizante sobre a poliamida-6 reciclada por termogravimetria e calorimetria exploratória diferencial. In: $2^{\circ}$ Congresso Brasileiro de Análise Térmica e Calorimetria, 1ํㅜㄴ Congresso Panamericano de Análise térmica e Calorimetria, Poços de Caldas, MG, Brasil. Livro de resumos, São Paulo, ABRATEC, 2000.

8. FERRO, W.P. Estudo do efeito da radiação ionizante nas propriedades da poliamida $6.6 \mathrm{com}$ e sem reforço de fibra de vidro. 2003, dissertação (Mestrado), - Instituto de Pesquisas Energéticas e Nucleares, São Paulo.

9. SCHNABEL, W. Polymer Degradation. Macmillan Publishing Co., New York, NY,1981.

10. YAMASAKI, M.C.R.; REIS, R.V.V.; ARAÚJO, E.P. Efeitos Químicos das Radiações lonizantes Gama e Feixe de Elétrons em Polímeros. In: 1ํำ 
Congresso Brasileiro de Polímeros, Novembro, 05-07, 1991, São Paulo - SP. Anais... São Paulo: ABPol, v.1, p.305-309, 1991.

11. WIEBECK H.; HARADA, J.; SANTOS, P.A.; OLIVEIRA, K.S. PMT - 5848 Plásticos de Engenharia. São Paulo, 2001.

12. SAECHTLING, H. Manuale delle Materie Plastiche. Tecniche Nuove, Edizione Italiana, Milano, 1996.

13. UNIÃO INTERNACIONAL DE QUÍMICA PURA E APLICADA. Compêndio de Nomenclatura Macromolecular. e-papers Serviços Editoriais Ltda., Rio de Janeiro, Brasil, IUPAC, cap. V, 2002.

14. ASCIUTTI, S.A. Poliamida 6 e 6.6, Produção e Transformação. Apostila Petronyl, 1997.

15. NELSON, W.E. Nylon Plastic Technology. London, The Plastics and Rubber Institute, 1976.

16. MANO, E.B. Polímeros como materiais de engenharia. Editora Edgard Blücher Ltda, São Paulo, 1991.

17. KOHAN, M.I. Nylon Plastics. Willey Interscience, New York, 1973.

18. AlfReY, T.; GURNEE, E.F. Polímeros Orgânicos. Editora Edgard Blücher Ltda, Brasil, 1971.

19. HARADA, J. Curso Polímeros para Embalagens. Brasil, Associação Brasileira de Polímeros, 2001.

20. RHODIA. TECHNYL polyamide range. Catálogo Rhodia Engineering Plastics Inc., 2005.

21. RADICI PLASTICS. Polyamide, range of materials. Catálogo Radiciplastics Ltda, , 2007.

22. BILLMEYER, F.W. Texbook of polymer science. John Wiley \& Sons, New York, NY, 1984.

23. RADICI NOVACIPS. Polyamides, Properties and Resistance to Chemicals Agents. Bergamo, Italy, 2001.

24. BRYDSON, J.A. Plastics Materials. Van Mostrand Reinhold Co., 2.ed, USA, 1970.

25. XILOLITE. Catálogo de produtos. Xilolite S/A, 2003. 
26. OURO BRANCO. Catálogo de produtos. Ouro Branco Minérios Ltda., 2005.

27. CT-MINERAL. Projeto de $\boldsymbol{P} \& \boldsymbol{D}$ em mineração de talco. Secretaria Técnica do Fundo Setorial Mineral, Centro de Gestão e Estudos Estratégicos, outubro, 2002.

28. DELLA, V.P. Processamento e caracterização de sílica ativa obtida a partir da cinza de casca de arroz. 2001, dissertação (Mestrado) - Universidade Federal de Santa Catarina, Florianópolis.

29. HOUSTON, D.F. Rice - Chemistry and Technology. American Association of Cereal Chemists, Minnesota, 1972.

30. FOLETTO, E.L.; HOFFMANN, R.; HOFFMANN, R.S.; PORTUGAL Jr., U.L.; JAHN, S.L. Aplicabilidade das Cinzas da Casca de Arroz. Revista Química Nova, v. 28, n.6, SP, Brasil, 2005, ISSN 0100-4042.

31. ARROZ BRASILEIRO - http://www.arroz.agr.br/site/arrozemfoco/040305.php Brasil pode gerar 200 megawatts de energia com a casca de arroz. Artigo de Mariana Perozzi, acessado em janeiro, 2004.

32. BIODIESEL $\mathrm{Br}-$ http://www.biodieselbr.com/energia/residuo/energia-doarroz.htm - Casca de Arroz: Energia. Artigo acessado em novembro, 2008.

33. ABRARROZ - http://www.abrarroz.com/Pages/menu.htm Associação Brasileira da Cadeia Produtiva do arroz, estatísticas, acesso em janeiro, 2004.

34. NAKATA, Y.; SUZUKI, M. Preparation and properties of $\mathrm{SiO}_{2}$ from rice hulls. Journal Ceramic Society of Japan International Edition. v. 97, 1989.

35. DAFICO, D.A. Método de produção de cinza de casca de arroz para utilização em concretos de alto desempenho. Artigo publicado no portal http://www.ucg.br/Institutos/nucleos/nupenge/index.htm; PUC de Goiás, Núcleo de Pesquisa em Engenharia (NUPENGE), acessado em janeiro, 2004.

36. SOUZA, M.F.; MAGALHÃES, W.L.E.; PERSEGIL, M.C. Silica Derived from Burned Rice Hull. Materials Rsearch. Brasil: v.5, n.4, 2002, ISSN 1516-1439.

37. DAFICO, D.A. Estudo da dosagem do concreto de alto desempenho utilizando pozolanas provenientes da casca de arroz. 2001, tese (doutorado) - Universidade Federal de Santa Catarina, Florianópolis. 
38. SCHMITZ, J.A.K.; SOUZA, P.V.D.; KÄMPF, A.N. Propriedades químicas e físicas de substratos de origem mineral e orgânica para o cultivo de mudas em recipientes. Ciência Rural, v.32 nำ, Santa Maria nov./dez. 2002, ISSN 0103-8478.

39. SOUZA, M.F.; YAMAMOTO, J. Mulita a partir de hidróxido de alumínio e de sílica da casca de arroz. Cerâmica vol.45 nํ 291, São Paulo, 1999, ISSN 0366-6913.

40. SOUZA, M.F.; YAMAMOTO, J.; REGIANI, I.; SANTOS, C.O.P.; SOUZA, D. P.F. Mullite Whiskers Grown from Erbio-Doped Aluminum Hydroxide-Silica Gel. Journal of the American Ceramic Society. USA: vol. 83, n.1, 2000.

41. COSTA, M.C.; VISCONTE, L.L.Y.; NUNES, R.C.R.; FURTADO, C.R.G. Vulcanization kinetics of natural rubber filled with rice husk ash. Polímeros vol.13, no 2, São Carlos, abr/jun. 2003, ISSN 0104-1428.

42. SOUZA, M.F.; BATISTA, P.S.; LIBORIO, J.B.L. Processo de Extração da Sílica Amorfa Contida na Casca e na Planta do Arroz. Patente: Privilégio de Inovação n.PI9903208, Processo de extração da sílica; 30 de Junho de 1999 (Depósito), 1999.

43. INTERSÍLICA. Microsílica MS 325. Catálogo Intersílica, 2007.

44. Encyclopedia of Polymer Science Engineering, v.13, 1988.

45. KIRCHER, J.F.; BOWMAN, R.E. Effects of Radiation on Materials and Components. Reinhold Publishing Corporation, New York, USA, 1964.

46. CHAPIRO, A. Radiation induced polymerization, Radiat. Phys. Chem. v 14, 1979.

47. O'DONNELL, J.H.; SANGSTER, D.F. Principles of radiation chemistry. E. Arnold, London, 1970.

48. CLEGG, D.W.; COLLYER, A.A. Irradiation Effects on Polymers. Elsevier Applied Science, London 1991.

49. CONSULTANTS BUREAU. ALL-UNION Conference on Radiation Chemistry. Consultants Bureau, USA, Inc., 1959. 
50. MARTUSCELLI, E.; MARCHETTA, C.; NICOLAIS, L. Future Trends in Polymer Science and Technology. Technomie Publishing Company Inc, USA, Pennsylvania, 1987.

51. SHAH, V. Handbook of plastics Testing Technology. A Wiley-Interscience publication, USA, 1983.

52. KOHAN, M.I. Engineered materials handbook. ASM International, New York, 1988.

53. MANRICH, S. Processamento de Termoplásticos. Art Líber Editora Ltda, SP, Brasil, 2005.

54. CANEVAROLO Jr., S V. Ciência dos Polímeros. Art Líber Editora Ltda., SP, Brasil, 2002.

55. RADICl. Resistência ao Impacto por queda de dardo. Procedimento laboratorial baseado na norma ASTM D5628, Radici Plastics, Brasil, 2008.

56. RADICI. Teor de carga. Procedimento laboratorial baseado na norma ISO 3451/4, Radici Plastics, Brasil, 2008.

57. ASSOCIAÇÃO BRASILEIRA DE NORMAS TÉCNICAS. Determinação da Resistência ao Calor Anormal, ao Fogo e à Corrente de Fuga. ABNT, (NBR 6272) Brasil, 1980.

58. LUCAS, E.F.; SOARES, B.G.; MONTEIRO E. Caracterização de Polímeros. epapers Serviços Editoriais Ltda., Rio de Janeiro, Brasil, 2001.

59. FELISBERTI, M.I. Caracterização de Blendas Poliméricas através de Análise Térmica e Termomecânica. Associação Brasileira de Polímeros, Unicamp/lQ - São Paulo, 1998.

60. NAGATA, N.; BUENO, M.I.M.S.; PERALTA-ZAMORA, P.G. Métodos matemáticos para correção de interferências espectrais e efeitos interelementos na análise quantitativa por fluorescência de Raios $X$. Revista Química Nova, vol. 24, №4, SP, Brasil, ISSN 0100-4042, 2001.

61. CANEVAROLO Jr., S.V. Técnicas de Caracterização de Polímeros, cap. 1.3.2, Fundamentos de fluorescência e difração de raios $X$ : geração de um feixe monocromático, por BAUMHARDT NETO, R.; Art Líber Editora Ltda., SP, Brasil, 2004. 
62. INTERNATIONAL STANDARD. Assessment of, and acceptance criteria for, the adhesion/cohesion (fracture strength) of a coating - Part 2: Cross-cut testing and X-cut testing. ISO 16276-2, third edition, 2007.

63. VOLKSWAGEN. Vernizes e tintas sobre material sintético, Resistência ao impacto de pedras. Especificação PV1217 referenced standards DIN 50 014, 1995.

64. PIOLTINI, G. Moldagem por injeção. Curso de treinamento e atualização em técnicas de moldagem, Radici Plastics, SP, Brasil, 2005. 